\title{
Silicon isotopes of deep sea sponges: new insights into biomineralisation and skeletal structure
}

\author{
Lucie Cassarino $^{1}$, Christopher D. Coath ${ }^{1}$, Joana R. Xavier ${ }^{2,3}$, and Katharine R. Hendry ${ }^{1}$ \\ ${ }^{1}$ University of Bristol, School of Earth Sciences, Wills Memorial Building, Queen's Road, Bristol, BS8 1RJ, UK \\ ${ }^{2}$ CIIMAR - Interdisciplinary Centre of Marine and Environmental Research, University of Porto, \\ Avenida General Norton de Matos, 4450-208 Matosinhos, Portugal \\ ${ }^{3}$ Department of Biological Sciences and K.G. Jebsen Centre for Deep Sea Research, University of Bergen, \\ P.O. Box 7803, 5020 Bergen, Norway
}

Correspondence: Lucie Cassarino (1.cassarino@bristol.ac.uk)

Received: 6 July 2018 - Discussion started: 10 July 2018

Revised: 24 October 2018 - Accepted: 26 October 2018 - Published: 21 November 2018

\begin{abstract}
The silicon isotopic composition $\left(\delta^{30} \mathrm{Si}\right)$ of deep sea sponges' skeletal element - spicules - reflects the silicic acid (DSi) concentration of their surrounding water and can be used as natural archives of bottom water nutrients. In order to reconstruct the past silica cycle robustly, it is essential to better constrain the mechanisms of biosilicification, which are not yet well understood. Here, we show that the apparent isotopic fractionation $\left(\delta^{30} \mathrm{Si}\right)$ during spicule formation in deep sea sponges from the equatorial Atlantic ranges from $-6.74 \%$ o to $-1.50 \%$ in relatively low DSi concentrations $(15$ to $35 \mu \mathrm{M})$. The wide range in isotopic composition highlights the potential difference in silicification mechanism between the two major classes, Demospongiae and Hexactinellida. We find the anomalies in the isotopic fractionation correlate with skeletal morphology, whereby fused framework structures, characterised by secondary silicification, exhibit extremely light $\delta^{30} \mathrm{Si}$ signatures compared with previous studies. Our results provide insight into the processes involved during silica deposition and indicate that reliable reconstructions of past DSi can only be obtained using silicon isotope ratios derived from sponges with certain spicule types.
\end{abstract}

\section{Introduction}

\subsection{Introduction to the Porifera world}

Sponges (phylum Porifera) are one of the most primitive metazoans and have likely occupied ocean sea floors since the Precambrian period as indicated by molecular fossil records from the end of the Marinoan glaciation $635 \mathrm{Myr}$ ago (Love et al., 2009) and Mongolian silica spicules dating from 545 million years ago (Antcliffe et al., 2014). Sponges are obligate sessile organisms, most of which are efficient filter feeders, capable of filtering $99 \%$ of the particles from water pumped through their internal body structure (Strehlow et al., 2017, and references therein). Most sponges secrete minerals such as calcite, aragonite and/or silica to build a complex and strong skeletal framework composed of elements called spicules, providing protection and the maximum of contact between cells and their surrounding water (Uriz et al., 2003). Of the biomineralising sponges, $92 \%$ of living species produce silica, compared to $8 \%$ that produce calcium carbonate skeletons (Hooper and Van Soest, 2002), but this ratio may have varied in the past due to changes in paleo-ocean chemistry (Montanez, 2002) because sponges rely on the ion chemistry of their surrounding water to build their skeleton.

Three classes of sponges in the phylum Porifera, Homoscleromorpha, Demospongiae and Hexactinellida, produce their spicules made of bio-silica (amorphous silica) through the incorporation and deposition of hydrated silica $\left(\mathrm{SiO}_{2} \cdot n \mathrm{H}_{2} \mathrm{O}\right)$, a process referred to as biosilicification (e.g. Uriz, 2006; Otzen, 2012). The spicules may represent up 
to $70 \%-90 \%$ of the body (dry weight) depending on the species (e.g Sandford, 2003; Maldonado et al., 2012). Demosponges and hexactinellids differ in their body structure and spicule shape and size, which are both highly variable. Siliceous spicules can be subdivided into megascleres (up to and beyond $300 \mu \mathrm{m}$ ) and microscleres (up to $50 \mu \mathrm{m}$ ) and are generally categorised by their size and their role in the skeletal framework (Uriz et al., 2003).

Demospongiae is the largest class of the phylum Porifera (Van Soest et al., 2012). Species within this class harbour monaxonic and/or tetraxonic megascleres with various shapes, as well as various types of microscleres, which compose their skeletal structure. Both mega- and microscleres are loose and unfused but joined by spongin (collagen protein) (Uriz, 2006). Demospongiae have a cellular organisation, i.e composed of cells that form tissues, which themselves form organs, which form an organism.

Hexactinellida, commonly called glass sponges, exhibit a wide range of body structures, such as tubular, cup-shaped and branching (Ereskovsky, 2010). The spicules of hexactinellid sponges are characterised by hexactins (three axes with regular angles), which can lose or gain rays, resulting in a wide range of shape and structure (Ereskovsky, 2010). One distinctive feature of the Hexactinellida class is that their spicules can be loose, partially or totally fused, or even cemented by a secondary silica layer and or junction (Uriz et al., 2003). One key feature that distinguishes between Demospongiae and Hexactinellida is that Hexactinellida are characterised by a syncytial organisation, i.e. tissue composed of cells without an individual plasma membrane (Leys and Lauzon, 1998; Maldonado and Riesgo, 2007).

Sponges have recently roused interest and are increasingly recognised as a key component of the marine silicon cycle (Tréguer and De La Rocha, 2013; Maldonado et al., 2005). They live on the sea floor at most latitudes and depths (De La Rocha, 2003; Wille et al., 2010; Maldonado and Riesgo, 2007; Maldonado et al., 2012) and may be considered a large living standing stock of silica in the oceans (Maldonado et al., 2010). Because of their relatively low growth rate and their inability to move, they are sensitive to change of their environment and because an individual sponge can live decades or centuries (Pansini and Pronzato, 1990; Leys and Lauzon, 1998) they can record information over long time periods (Jochum et al., 2017).

\subsection{Silicon isotope and deep sea sponges}

The silicon isotopic composition of biogenic silica $\left(\delta^{30} \mathrm{BSi}\right)$ has been introduced to study the past nutrient utilisation by De La Rocha et al. (1997) and since has been used to study the silicon cycle (e.g Hendry et al., 2016; Fontorbe et al., 2017). Silicon is composed of three stable isotopes, ${ }^{28} \mathrm{Si}$, ${ }^{29} \mathrm{Si}$ and ${ }^{30} \mathrm{Si}$, with relative abundances of approximatively $92.23 \%, 4.67 \%$ and $3.10 \%$ respectively (De Bièvre and Taylor, 1993). Silicon isotopic abundances in samples (SMP) are expressed as $\delta^{29} \mathrm{Si}$ or $\delta^{30} \mathrm{Si}$ with the abundance ratio, ${ }^{29} \mathrm{Si} /{ }^{28} \mathrm{Si}$ or ${ }^{30} \mathrm{Si} /{ }^{28} \mathrm{Si}$ respectively, and measured relative to the reference standard (NBS28). The results presented in this study are expressed as per mille to be consistent with the International Union of Pure and Applied Chemistry (IUPAC) nomenclature, i.e.

$\delta^{x} \mathrm{Si}(\% \circ)=\left(\frac{\left(\frac{x}{{ }^{2} \mathrm{Si}}\right)}{\left(\frac{x \mathrm{Si}}{{ }^{28} \mathrm{Si}}\right)_{\mathrm{SMP}}}-1\right)$.

The $\delta^{30} \mathrm{Si}$ signature of deep sea sponges has been highlighted as a potential paleoceanographic proxy for silicic acid DSi concentration (De La Rocha, 2003; Hendry et al., 2010; Wille et al., 2010; Hendry and Robinson, 2012). The asymptotic relationship between DSi concentration and $\delta^{30} \mathrm{Si}$ signature of sponge spicules $\left(\delta^{30} \mathrm{Si}_{\text {Spicules }}\right)$ is the result of the preferential incorporation of the lighter isotope (Wille et al., 2010; De La Rocha, 2003; Hendry et al., 2011). There is also a significant correlation between the apparent fractionation factor, $\delta^{30} \mathrm{Si}\left(\delta^{30} \mathrm{Si}_{\text {Spicules }}-\delta^{30} \mathrm{Si}_{\mathrm{DSi}}\right)$, and the ambient DSi concentration (Hendry and Robinson, 2012). The relationship between $\delta^{30} \mathrm{Si}_{\text {Spicules }}$ and DSi concentration is not yet understood, but a simple biological model suggests that the fractionation factor could arise during sponge uptake, polymerisation and efflux (Wille et al., 2010; Hendry and Robinson, 2012). Thus, $\delta^{30} \mathrm{Si}_{\text {Spicules }}$ is a potential proxy to quantify ocean changes in Si cycling with a larger spatial range and timescales than diatoms (De La Rocha, 2003; Fontorbe et al., 2017). Furthermore, the dissolution rate of sponge spicules is lower than that of diatoms' frustules (Maldonado et al., 2005), which may result in a better preservation. A calibration of modern sponge specimens and core-top spicules from different oceans shows that the core-top specimens are not affected by post-depositional dissolution or even early diagenesis (Hendry and Robinson, 2012), which are both potential concerns when dealing with the chemistry of reactive biogenic opal (Ragueneau et al., 2001; De La Rocha et al., 2011).

Despite the great potential of sponges as archives of past ocean Si cycling, there are still a number of outstanding questions relating to $\mathrm{Si}$ isotopic fractionation. Does $\mathrm{Si}$ isotopic fractionation remain constant during sponge growth? Can we trace DSi concentration over time by analysing $\delta^{30} \mathrm{Si}$ sections of sponge skeleton? At what stage during biomineralisation does the $\mathrm{Si}$ isotopic fractionation occur, and does it vary with spicule morphology? Here, some of these questions are going to be addressed by investigating $\delta^{30} \mathrm{Si}$ of modern deep sea sponges collected from the equatorial Atlantic. 


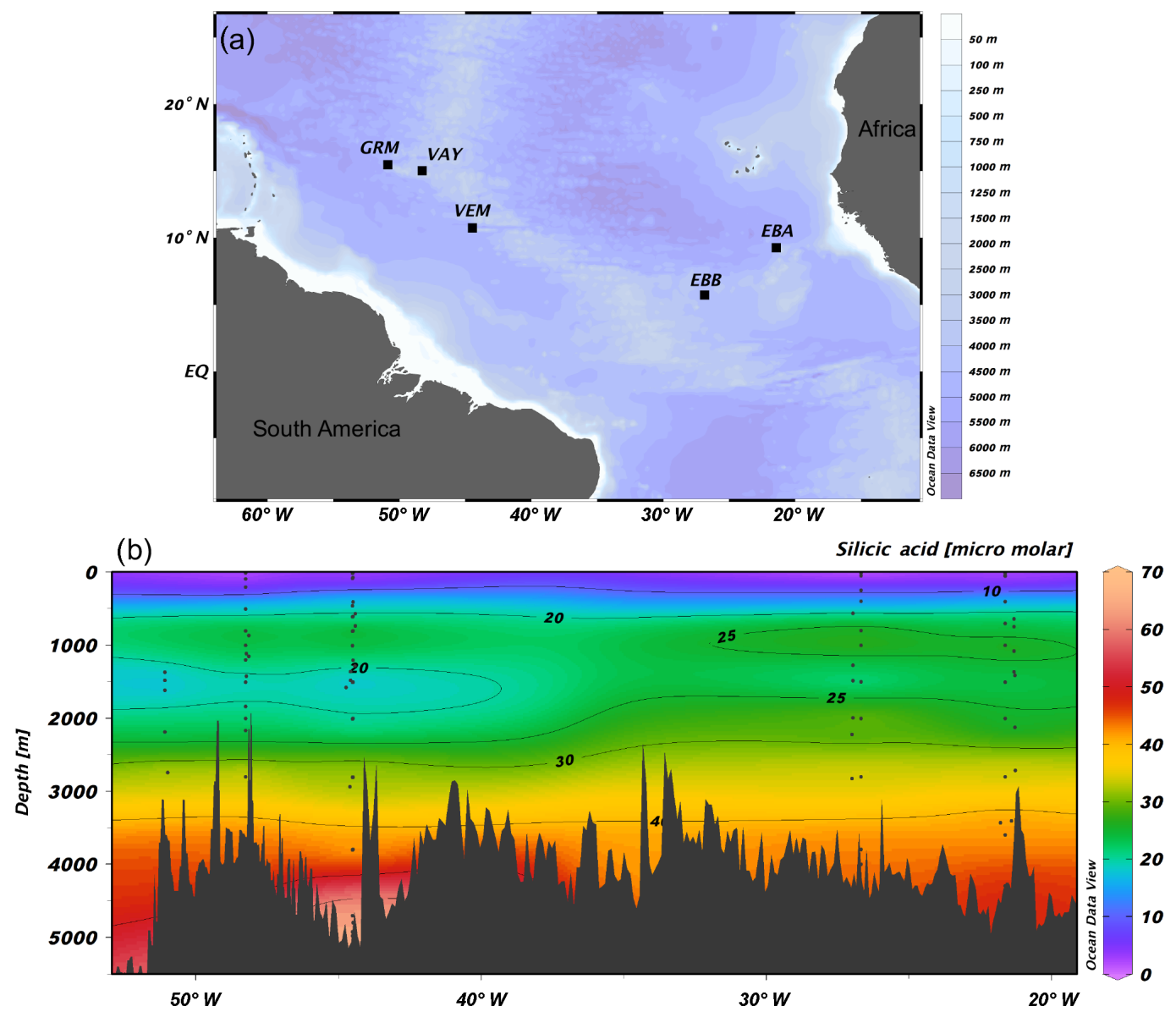

Figure 1. (a) JC094 sampling stations from the equatorial Atlantic. From east to west: EBA (Carter Seamount), EBB (Knipovich Seamount), VEM (Vema Fracture Zone), VAY (Vayda Seamount) and GRM (Gramberg Seamount). Cross section of DSi concentration in micromolar along the JC094 transect. Dots representing the sampling depth of stations, from east to west: EBA, EBB, VEM, VAY and GRM.

\section{Material and methods}

\subsection{Sample collection}

Sponge samples were collected by a remotely operated vehicle (ROV) at five stations, EBA, EBB, VEM, VAY and GRM, between 298 and $2985 \mathrm{~m}$ (Fig. 1) aboard the RRS James Cook on the TROPICS cruise (JC094), a west-east cross section in the equatorial Atlantic between $\sim 5$ and $\sim 15^{\circ} \mathrm{N}$, from 13 October to 30 November 2013. Seawater samples were sampled using Niskin bottles attached to CTD rosette system and occasionally by a ROV at each station. Whilst the best attempts were made to spatially match the sponge and water samples, it was not always possible to collect precisely co-located sponge and seawater samples. The $\delta^{30} \mathrm{Si}_{\mathrm{DSi}}$ values are reported in Table A1 (Appendix) and, for each sponge specimen, the closest seawater sample is used to calculate $\Delta^{30} \mathrm{Si}$.

The sponge specimens were sampled as either large individual sponges or smaller individuals encrusted on other organisms such as corals. Subsamples were dried for transportation to the UK. Preliminary assignment of the specimens to the classes Demospongiae and Hexactinellida was carried out onboard using binocular and petrological microscopes. Identifications to lower taxonomic ranks, combining morphological and molecular methods, are underway and will be published in a separate paper.

\subsection{Sponge spicule cleaning procedure and $\mathrm{Si}$ pre-concentration from seawater}

For $\delta^{30} \mathrm{Si}_{\text {Spicules, }}$, organic matter (OM) was removed using hydrogen peroxide $\left(\mathrm{H}_{2} \mathrm{O}_{2}, 30 \%\right.$ reagent grade). Subsamples of dry sponge specimens were transferred into $50 \mathrm{~mL}$ Eppendorf tubes, covered with $\mathrm{H}_{2} \mathrm{O}_{2}$ (30\% reagent grade) for $24 \mathrm{~h}$ at room temperature and then heated for $3 \mathrm{~h}$ with new $\mathrm{H}_{2} \mathrm{O}_{2}$ (30\% reagent grade) at $85^{\circ} \mathrm{C}$. The samples were rinsed with 18.2 $\mathrm{M} \Omega$ Milli-Q water and heated for a further $3 \mathrm{~h}$ with fresh $\mathrm{H}_{2} \mathrm{O}_{2}$, before a final Milli-Q rinse. Samples were transferred into clean Teflon vials to undergo further cleaning, 
three times in concentrated $(16 \mathrm{~N})$ in-house Teflon-distilled $\mathrm{HNO}_{3}$, rinsing between each stage with Milli-Q water. If remaining, lithogenic material was removed by hand before further cleaning steps. A subsample was taken and weighed before going through a final cleaning step. The subsample was covered with $\mathrm{HNO}_{3}$ (16 N Romil) and dried down at $120^{\circ} \mathrm{C}$. When the spicules were dried, each sample was dissolved in $0.4 \mathrm{M} \mathrm{NaOH}$ (Analar) at $100^{\circ} \mathrm{C}$ for 3 days, following published protocols (Ragueneau et al., 2005; Cardinal et al., 2007; Hendry and Robinson, 2012). Samples were acidified with $8 \mathrm{~N} \mathrm{HNO}_{3}$ and diluted with Milli-Q water to reach a $\mathrm{pH}$ of $2-3$. This cleaning procedure followed the technique in Hendry et al. (2010) and Hendry and Robinson (2012).

Prior to isotopic analysis of seawater, $\mathrm{Si}$ was preconcentrated using the MAGIC method (magnesium-induced co-precipitation) of Karl and Tien (1992) with Reynolds et al. (2006) modifications. Brucite was precipitated overnight by the addition of $1.2 \% v / v 1 \mathrm{M} \mathrm{NaOH}$. After centrifugation (3000 $\mathrm{g}$ force for $3 \mathrm{~min}$ ) the supernatant was transferred and $1 \% v / v 1 \mathrm{M} \mathrm{NaOH}$ was added and left overnight in order to extract any residual silicon. The two precipitates were combined and rinsed with $0.001 \mathrm{M} \mathrm{NaOH}$ solution to remove remaining salt matrix before a final separation by centrifugation. Finally the precipitate, $\mathrm{Mg}(\mathrm{OH})_{2}$, was dissolved by adding $8 \mathrm{~N} \mathrm{HNO}_{3}$, resulting in a $\mathrm{pH}$ range of $1-3$. The yield recovery of $\mathrm{Si}$ is equivalent to $92.1 \%$.

\subsection{Analytical procedures}

For $\delta^{30} \mathrm{Si}$ analysis, pre-treated spicules and seawater samples were purified through cation ion exchange chromatography (Bio-Rad AG50W X12, 200-400 mesh in $\mathrm{H}^{+}$form). Analysis of $\delta^{30} \mathrm{Si}_{\text {Spicules }}$ and $\delta^{30} \mathrm{Si}_{\mathrm{DSi}}$ was carried out by multi-collector inductively coupled plasma mass spectrometry (MC-ICP-MS, Finnigan Neptune s/n 1002) at the Bristol Isotope Group facilities, University of Bristol. All sample analyses were repeated at least twice and followed the typical standard-sample bracketing and $\mathrm{Mg}$ doping methods from Cardinal et al. (2003) with the best intensity match possible between samples and bracketing standards. Measurement of secondary standards LMG-08 and Diatomite give $\delta^{30} \mathrm{Si}$ values of $-3.44 \pm 0.16 \%$ ( $\left.2 \mathrm{SD}, n=173\right)$ and $1.23 \pm 0.15 \%$ o ( $2 \mathrm{SD}, n=41)$ respectively. The external reproducibility of $\mathrm{Si}$ isotope measurements is $\pm 0.13 \%$ and $\pm 0.17 \%$ o ( $2 \mathrm{SD}$, degrees of freedom $=212$ ) for $\delta^{29} \mathrm{Si}$ and $\delta^{30} \mathrm{Si}$ respectively, for which the analytical scatter for both standards has been pooled (Steele et al., 2012). For comparison, Hendry et al. (2011) and Reynolds et al. (2007) report $\delta^{30} \mathrm{Si}=-3.37 \pm 0.17 \%$ and $\delta^{30} \mathrm{Si}=1.26 \pm 0.20 \%$ o for LMG-08 and Diatomite respectively. The new seawater standard ALOHA deep was analysed as an additional quality check and yielded values within error of those obtained during an interlaboratory study (Grasse et al., 2017): ALOHA deep: $\delta^{30} \mathrm{Si}=1.08 \pm 0.12 \%$ and $\delta^{29} \mathrm{Si}=0.58 \pm$
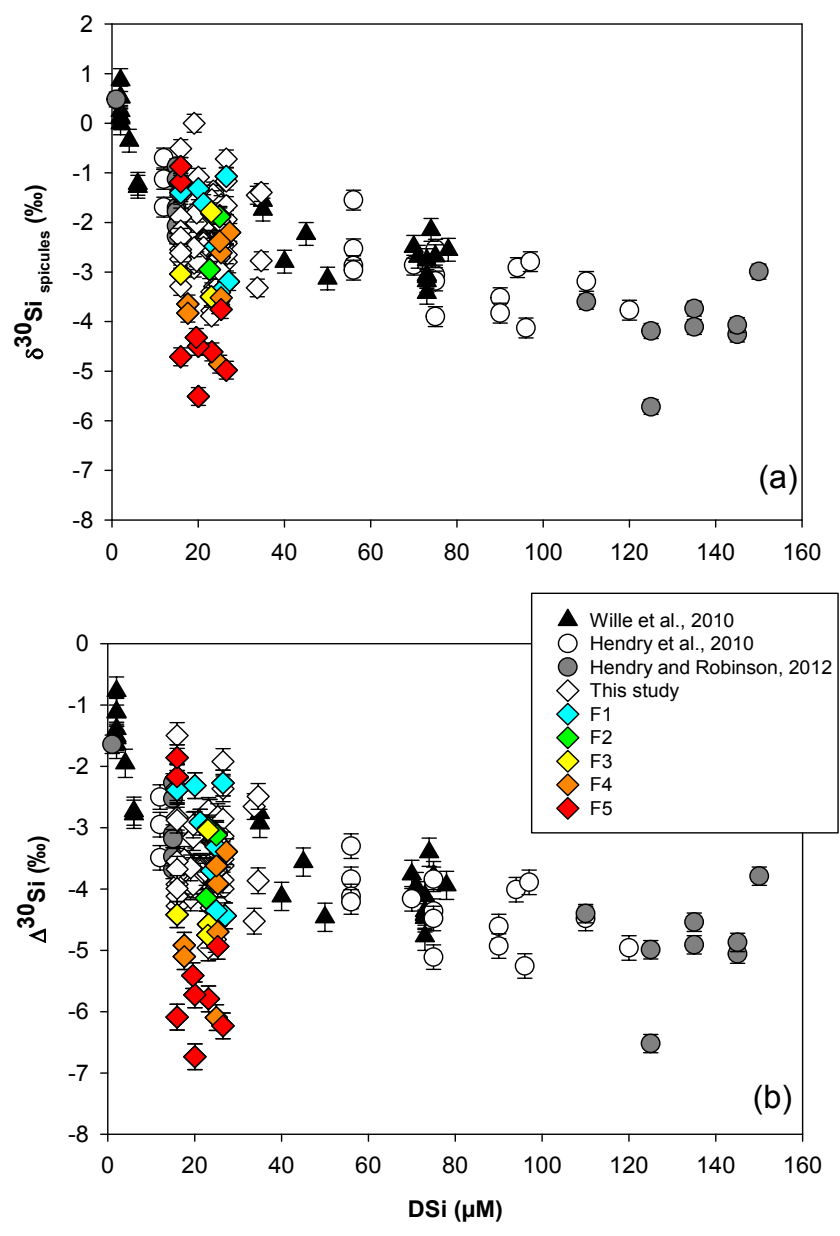

Figure 2. Sponge calibration data from Hendry et al. (2010) (Drake Passage and Scotia Sea), Wille et al. (2010) (Antarctica, Tasmania and New Zealand), Hendry and Robinson (2012) (North Atlantic, west Antarctic Peninsula, Woods Hole and North Pacific), and data from this study (equatorial Atlantic, JC094). (a) Silicon isotopic composition of the spicules $\left(\delta^{30} \mathrm{Si}_{\text {Spicules }}\right)$ and (b) deep sea sponges' apparent $\mathrm{Si}$ isotopic fractionation $\left(\delta^{30} \mathrm{Si}\right)$ against DSi concentration. Error bars for this study show $2 \mathrm{SD}, \pm 0.13$ for $\delta^{30} \mathrm{Si}_{\text {Spicules }}$ and \pm 0.17 for $\delta^{30} \mathrm{Si}$. NB: core-top samples from Hendry and Robinson (2012) are not included.

$0.12 \%$ ( $2 \mathrm{SD}, n=4)$. The $\delta^{29} \mathrm{Si}$ and $\delta^{30} \mathrm{Si}$ of all seawater and sponge samples are consistent with the kinetic mass fractionation law (Reynolds et al., 2007); i.e. $\delta^{29} \mathrm{Si}$ vs. $\delta^{30} \mathrm{Si}$ has a slope of $0.516\left(\mathrm{SE}=0.002, n=362, r^{2}=0.995\right)$. The results are reported relative to the standard NBS28 (Eq. 1).

\subsection{Scanning electron microscope images}

Scanning electron microscope (SEM) images of sponge spicules have been carried out at the University of Bristol on a Hitachi S-3700N SEM. Clean spicules were sputter-coated with $10 \mathrm{~nm}$ of gold. The instrument operated at an acceleration voltage of $15 \mathrm{kV}$ in second electron image mode. 


\section{Results}

\section{$3.1 \quad \delta^{30} \mathrm{Si}$ of deep sea sponges}

Data from the equatorial Atlantic exhibit $\delta^{30} \mathrm{Si}_{\text {Spicules }}$ from -5.51 to $-0.51 \pm 0.13 \%$ ( $2 \mathrm{SD})$ and $\delta^{30} \mathrm{Si}$ from -6.74 to $-1.50 \pm 0.17 \%$ o ( $2 \mathrm{SD}$ ) (Fig. 2, a and b respectively), representing the greatest $\delta^{30} \mathrm{Si}$ observed in sponges to date (Hendry et al., 2010; Wille et al., 2010; Hendry and Robinson, 2012). Detailed results are presented in Table A1 in the Appendix. The results have been added to the existing calibration from Hendry et al. (2010), Wille et al. (2010), and Hendry and Robinson (2012) (Fig. 2), showing that our new data are largely consistent with the existing calibration. However, a number of specimens deviate from the published calibration and record unusually light isotopic signatures.

\subsection{Degrees of spicule fusion}

The SEM images from all sponges showing a $\delta^{30} \mathrm{Si}$ larger than $-5 \%$ and from 20 other samples chosen randomly within a lower $\delta^{30} \mathrm{Si}$ range $\left(-1.50 \% \circ<\Delta^{30} \mathrm{Si}<-5 \%\right.$ ) have highlighted a variety of spicule shapes and degrees of skeletal fusion. In the bulk of sponge samples two groups can be identified: sponges with loose spicules with $\delta^{30} \mathrm{Si}_{\text {Spicules }}$ following the published calibration curve and sponges with fused spicules with ${ }^{30} \mathrm{Si}_{\text {Spicules }}$ deviating from the published calibration curve.

Further, the SEM images of spicules with various $\delta^{30} \mathrm{Si}_{\text {Spicules }}$ signatures reveal five levels of fusion, defined here as F1, F2, F3, F4 and F5. Level F1 represents loose spicules, F2 spicules fused by a node (netlike feature), F3 loose spicules fused in parallel with additional silica coating, F4 light dictyonal skeleton and F5 dense dictyonal skeleton; see Fig. 3 for SEM image examples and Table 1 for a detailed description of the fusion degree from F1 to F5. It is observed that ${ }^{30} \mathrm{Si}_{\text {Spicules }}$ and $\delta^{30} \mathrm{Si}$ show an enrichment in light isotopes with a higher degree of spicule fusion (see Fig. 4).

\section{Discussion}

\section{1 $\quad \delta^{30} \mathrm{Si}$ fractionation by deep sea sponges}

The new data presented here, from the equatorial Atlantic, show to date the largest range of $\delta^{30} \mathrm{Si}_{\text {Spicules }}$ signatures and $\delta^{30} \mathrm{Si}$ for a small range in DSi concentration $(15$ to $35 \mu \mathrm{M})$. As $\delta^{30} \mathrm{Si}$ larger than $-5 \%$ or this DSi range deviates from the published calibration curve, particular attention has been paid to these samples in order to understand the factors causing this large Si isotopic fractionation. SEM images show that these specimens have a common feature: a fused dictyonal framework skeleton. The following discussion introduces in more detail the fractionation of $\mathrm{Si}$ isotopes by sponges and the hypotheses relating to the large $\delta^{30} \mathrm{Si}$ values from the dictyonal skeleton.
Previous studies tracking the $\delta^{30} \mathrm{Si}$ of sponge silica have shown a non-linear relationship between ${ }^{30}{ }^{30} i_{\text {Spicules }}$ signatures and DSi concentration (Wille et al., 2010; Hendry and Robinson, 2012). The Si isotopic fractionation by sponges can be expressed with either $\delta^{30} \mathrm{Si}$ or $\varepsilon_{\mathrm{f}}$ notation. Here ${ }^{30} \mathrm{Si}$ is defined by the difference between $\delta^{30} \mathrm{Si}_{\text {Spicules }}$ and $\delta^{30} \mathrm{Si}_{\mathrm{DSi}}$, which describes the observed apparent $\mathrm{Si}$ isotopic fractionation by sponges, whereas $\varepsilon_{\mathrm{f}}$ is the result from the biological model from Wille et al. (2010) (Eq. 2). Published data have shown $\delta^{30} \mathrm{Si}$ varying from $-0.77 \%$ o to $-6.52 \%$ o (Fig. 2b), which follow a non-linear relationship and cannot be described by a diatom-like Rayleigh fractionation (characterised by a constant fractionation factor during DSi utilisation) because isotopic fractionation during the uptake of DSi by sponges is variable, increasing with DSi concentration. Wille et al. (2010) proposed a model following Milligan et al. (2004), which suggests that $\mathrm{Si}$ isotopic fractionation in marine sponges is mainly controlled by Si uptake. Reincke and Barthel (1997) first investigated the formation of BSi (i.e. silicification) in cultured sponges by regeneration of sponge pieces and, more recently, Si uptake has been investigated in culture using whole sponges collected at sea that were then transferred to a controlled environment (Maldonado et al., 2011; López-Acosta et al., 2016, 2018). Despite the different set-up and species chosen for each experiment, all culture experiments carried out to date suggest that the silicification in sponges is controlled by enzymatic processes, exhibiting Michaelis-Menten enzyme kinetics, and is dependent on substrate concentration, here DSi. From the close resemblance of the DSi and $\delta^{30} \mathrm{Si}_{\text {Spicules }}$ relationship and the growth rate kinetics, Wille et al. (2010) proposed a model from which $\delta^{30} \mathrm{Si}$ is fractionated during the uptake phase and internal spicule formation. The related fractionation of $\mathrm{Si}$ isotopes is expressed as $\varepsilon_{\mathrm{f}}$ (Eq. 2), with DSi concentration being the main factor influencing $\delta^{30} \mathrm{Si}_{\text {Spicules }}$.

$\varepsilon_{\mathrm{f}}=\varepsilon_{t I}+\left(\varepsilon_{p}-\varepsilon_{E}\right)\left\{1-\frac{\frac{V_{\max , \mathrm{P}}}{\left(\frac{K_{\mathrm{m}, \mathrm{P}}}{\mathrm{DSi}}\right)+1}}{\frac{V_{\max , \mathrm{I}}}{\left(\frac{K_{\mathrm{m}, \mathrm{I}}}{\mathrm{DS}}\right)+1}}\right\}$,

where $\varepsilon_{\mathrm{tI}}$ is the $\mathrm{Si}$ isotopic fractionation during Si uptake, $\varepsilon_{\mathrm{p}}$ is the $\mathrm{Si}$ isotopic fractionation during polymerisation, $\varepsilon_{\mathrm{E}}$ is the $\mathrm{Si}$ isotopic fractionation during the efflux, $V_{\max , \mathrm{P}}$ and $V_{\max , \mathrm{I}}$ are the maximum polymerisation and incorporation rates respectively, $K_{\mathrm{m}, \mathrm{P}}$ and $K_{\mathrm{m}, \mathrm{I}}$ are the half saturation constant of polymerisation and incorporation respectively, and DSi is the silicic acid concentration of the surrounding water.

Hendry and Robinson (2012) applied this model to a wide range of modern sponges from different ocean basins showing that the temperature, one of the factors controlling enzymatic processes, does not affect the relationship between $\delta^{30} \mathrm{Si}$ and DSi concentration, which supports DSi concentration being the main factor controlling $\mathrm{Si}$ isotopic fractionation. Despite the small range of seawater temperature in this 


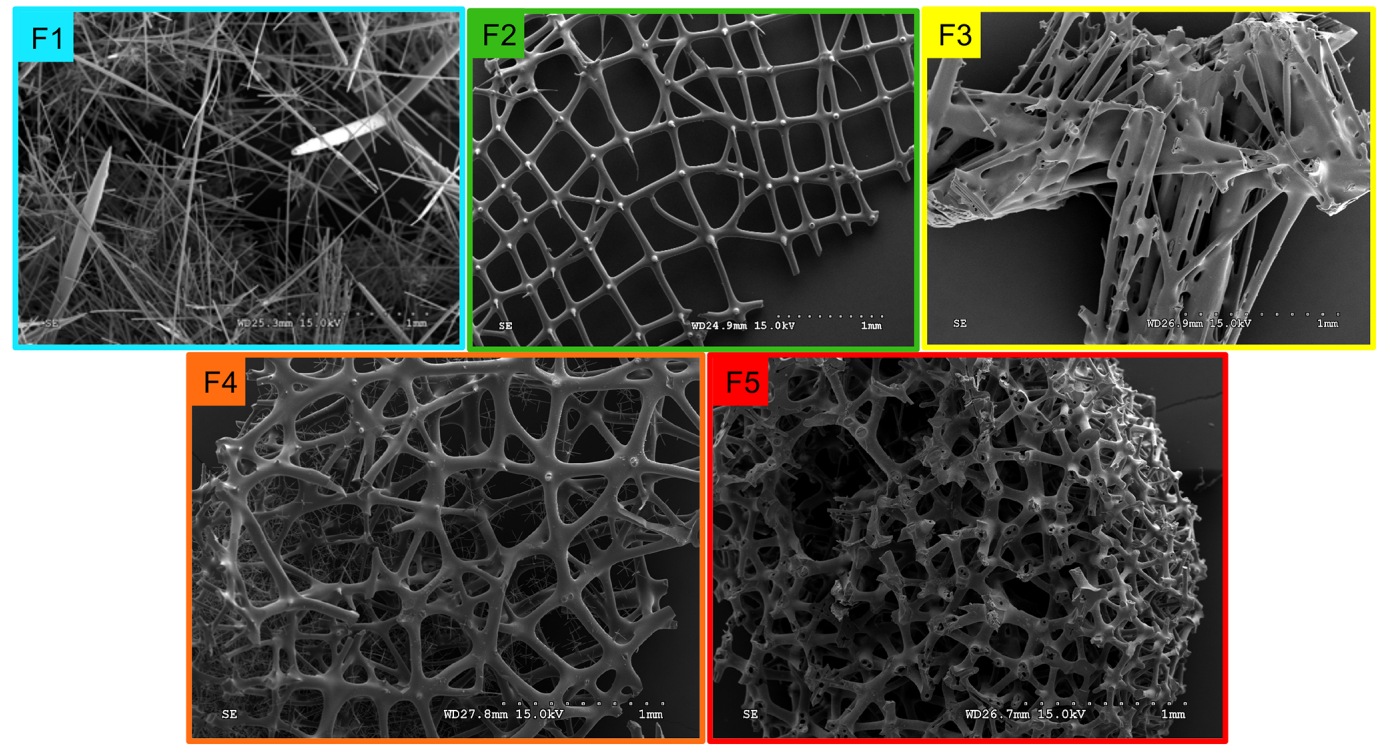

Figure 3. Level of fusion of sponge spicules from the equatorial Atlantic. F1 (blue) loose spicule, F2 (green) net-like, F3 (yellow) additional silica coating, F4 (orange) light dictyonal skeleton and F5 (red) dense dictyonal skeleton.

Table 1. Criteria of the five levels of sponge spicule fusion. See Fig. 3 for the corresponding picture.

\begin{tabular}{|c|c|c|c|}
\hline Fusion level & Given name & Class & Description \\
\hline $\mathrm{F} 1$ & Loose & Demospongiae/Hexactinellida & $\begin{array}{l}\text { Single loose microsclere and/or megasclere } \\
\text { spicules }\end{array}$ \\
\hline $\mathrm{F} 2$ & Net-like & Hexactinellida & $\begin{array}{l}\text { Spicules fused perpendicularly fused by a node } \\
\text { forming a relatively regular two-dimensional } \\
\text { net }\end{array}$ \\
\hline F3 & Parallel coating & Hexactinellida & $\begin{array}{l}\text { Spicules fused in parallel and/or multi-angled } \\
\text { by additional silica coating }\end{array}$ \\
\hline $\mathrm{F} 4$ & Light dictyonal skeleton & Hexactinellida & $\begin{array}{l}\text { Spicules fused/cemented by a node of } \\
\text { six branches and forming a three-dimensional } \\
\text { framework }\end{array}$ \\
\hline F5 & Dense dictyonal skeleton & Hexactinellida & $\begin{array}{l}\text { Spicules fused/cemented by a node of } \\
\text { six branches and forming a three-dimensional } \\
\text { framework; void space between the spicule } \\
\text { smaller than F4 and presence of lots of holes } \\
\text { within the spicules }\end{array}$ \\
\hline
\end{tabular}

study, our data show no relationship between $\delta^{30} \mathrm{Si}$ and temperature (Fig. A1 in Appendix). However, here a group of sponges from the equatorial Atlantic exhibit a different relationship between $\delta^{30} \mathrm{Si}$ and DSi concentration with a very large apparent fractionation, $\Delta^{30} \mathrm{Si}<-5 \%$, at low concentration $(15$ to $35 \mu \mathrm{M})$. Figure $4 \mathrm{a}$ shows the variability in $\delta^{30} \mathrm{Si}$ for each fusion stage and that the fusion degree of the spicules appears to affect $\delta^{30} \mathrm{Si}$. Furthermore Fig. 4b shows the $\delta^{30} \mathrm{Si}$ residual of the same samples against the previous published calibration (Hendry et al., 2010; Wille et al., 2010; Hendry and Robinson, 2012), which suggests that processes other than silicic acid concentration are involved in the fractionation of $\mathrm{Si}$ isotopes.

Dictyonal framework skeletons, F4 and F5, only belong to the Hexactinellida class, which could suggest that the two classes have a different $\mathrm{Si}$ isotopic fractionation due to their different silicification mechanism (Maldonado and Riesgo, 2007). The $\delta^{30} \mathrm{Si}_{\text {Spicules }}$ average signature of the two siliceous sponge families from the compiled data presented in Fig. 2 (Hendry and Robinson, 2012, Wille et al., 2010, Hendry et al., 2010, with the equatorial Atlantic data (JC094)) show that the Hexactinellida class is significantly lighter than Demospongiae, with $\delta^{30} \mathrm{Si}_{\text {Spicules }}=-2.66 \pm 0.21 \%$ (CI (confi- 

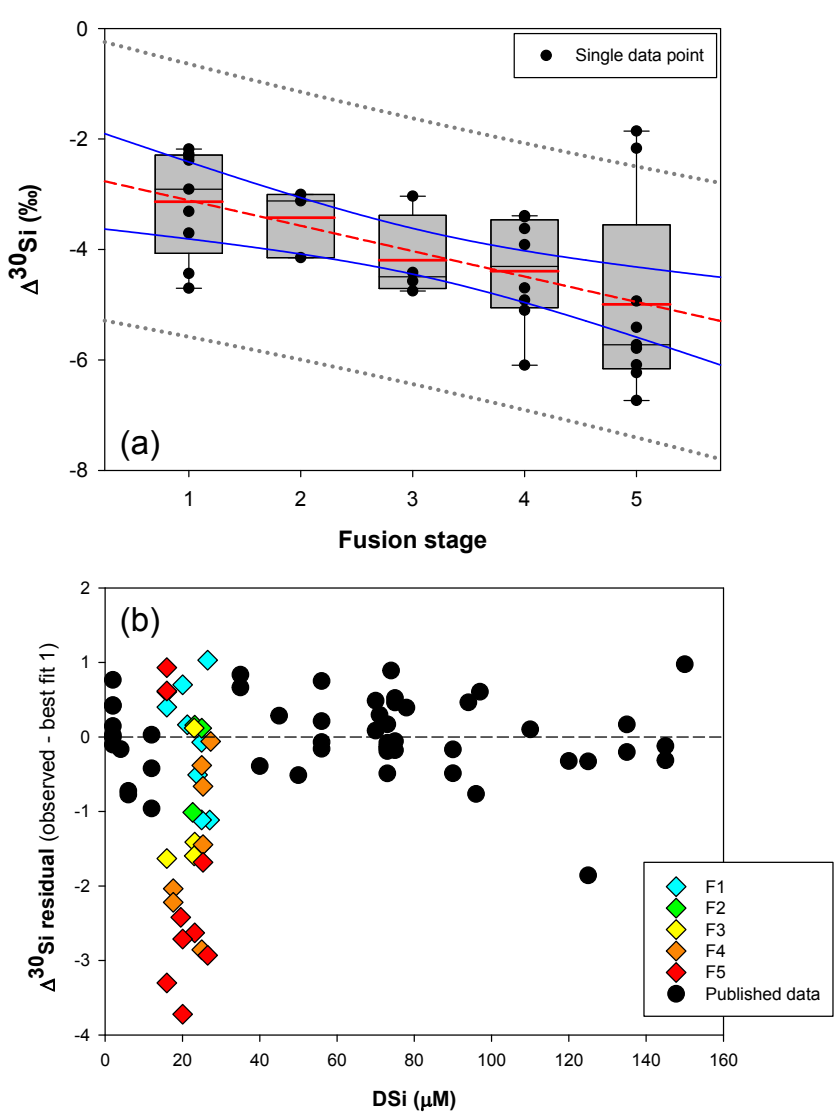

Figure 4. (a) Box plot showing the apparent $\mathrm{Si}$ isotopic fractionation $\delta^{30} \mathrm{Si}$ by sponges as a function of spicule fusion degree: 1 for loose spicules (F1), 2 for net-like (F2), 3 for additional silica coating (F3), 4 for dictyonal framework (F4) and 5 for dense dictyonal framework (F5). Red lines in the box plots are the mean of each population and black is the median. The boxes define the 25 th and the 75th percentiles and the error bars are the 10th and 90th percentiles. Black circles show a single sample for each of the fusion stages and the red dashed line shows the significant linear relationship between $\delta^{30} \mathrm{Si}$ and the fusion stage of the spicule $(n=33, p<0.0011)$. The blue lines represent the $95 \%$ confidence band and the grey short dashed lines the $95 \%$ prediction band. Data plotted here correspond to the samples from the equatorial Atlantic with an identified fusion stage, i.e. coloured diamond of (b), and so occupy a very narrow range of DSi. (b) $\delta^{30} \mathrm{Si}$ residual of samples with an identified fusion stage compared to the published calibration (best fit 1).

dence interval) of the mean) and $-1.91 \pm 0.30 \%$ (CI of mean) respectively. However, it is important to take into consideration the environmental conditions of growth because ${ }^{30}{ }^{30} i_{\text {Spicules }}$ depends on the ${ }^{30} \mathrm{Si}$ and DSi concentration of seawater and the two groups live at different depth ranges and nutrient conditions. To eliminate the influence of these two parameters and resolve whether or not Demospongiae and Hexactinellida fractionate $\mathrm{Si}$ isotopes in different ways, a $\delta^{30} \mathrm{Si}$ residual has been calculated: $\delta^{30} \mathrm{Si}$ residual $=\Delta^{30} \mathrm{Si}_{\text {Observed }}-\Delta^{30} \mathrm{Si}_{\text {Spiculesbestfit. Three best fits have }}$ been calculated assuming the hyperbolic relationship between DSi and $\delta^{30} \mathrm{Si}$ (Hendry and Robinson, 2012) to deconvolve the influence of fused skeleton. Equations (3), (4) and (5) correspond to the best-fit curves (number in parentheses are the standard error) in Fig. 5, for

1. the previous compilation from Hendry and Robinson (2012), Wille et al. (2010) and Hendry et al. (2010),

$$
\Delta^{30} \mathrm{Si}=-5.39(0.4)+111.51(11.3) /(26.87(11.2)+\mathrm{DSi}) ;
$$

2. the previous compilation from Hendry and Robinson (2012), Wille et al. (2010) and Hendry et al. (2010) with this study data,

$$
\Delta^{30} \mathrm{Si}=-4.69(0.2)+30.89(2.7) /(7.29(2.7)+\mathrm{DSi})
$$

3. the previous compilation from Hendry and Robinson (2012), Wille et al. (2010) with Hendry et al. (2010) with this study without the dictyonal skeleton,

$$
\Delta^{30} \mathrm{Si}=-4.71(0.18)+34.25(2.6) /(8.29(2.6)+\mathrm{DSi}) .
$$

Figure $5 \mathrm{~b}, \mathrm{~d}$, and $\mathrm{f}$ show $\delta^{30} \mathrm{Si}$ residual results of each class, calculated from the best fit (Fig. 5a, c, e, respectively) with the compilation (a) of published data (Hendry and Robinson, 2012; Wille et al., 2010; Hendry et al., 2010), (b) of published and all JC094 data, and (c) of published and JC094 data without the fused spicules (F1 to F5). Only the samples with class identification are include in the three residual results. The results of these residual tests show that there is no disparity between the two classes even with the incorporation of the dictyonal framework (Fig. 5b, d, f). The residual test, however, highlights that hexactinellids have a tendency to live in water with a higher DSi concentration compared to demosponges, which supports the idea that the $\mathrm{Si}$ isotopic fractionation is driven by DSi concentration. Furthermore, when data from all JC094 data are incorporated into the published calibration curve (Fig. 5c), the dictyonal framework (F4 and F5) is not included in the $95 \%$ confidence limits (red lines). This observation illustrates that sponges with fused spicules, in particular dictyonal frameworks F4 and F5, cannot yet be used as a robust proxy for ocean chemistry.

The question still remains as to what controls the large ${ }^{30} \mathrm{Si}$ observed for sponges with complex dictyonal framework skeletons. Two main hypotheses are proposed and discussed in order to deconvolve $\delta^{30} \mathrm{Si}_{\text {Spicules }}$ and fusion type.

\subsection{Spicule composition: a control of $\delta^{30} \mathrm{Si}$ ?}

The primary hypothesis concerns the structure of the spicule itself. Recently He et al. (2016) have shown, using chemical modelling, that there is an extremely large $\mathrm{Si}$ isotopic fractionation of $-9.1 \% \circ$ at $25{ }^{\circ} \mathrm{C}$ between hyper-coordinated organosilicon complexes and DSi. This paper has raised the 

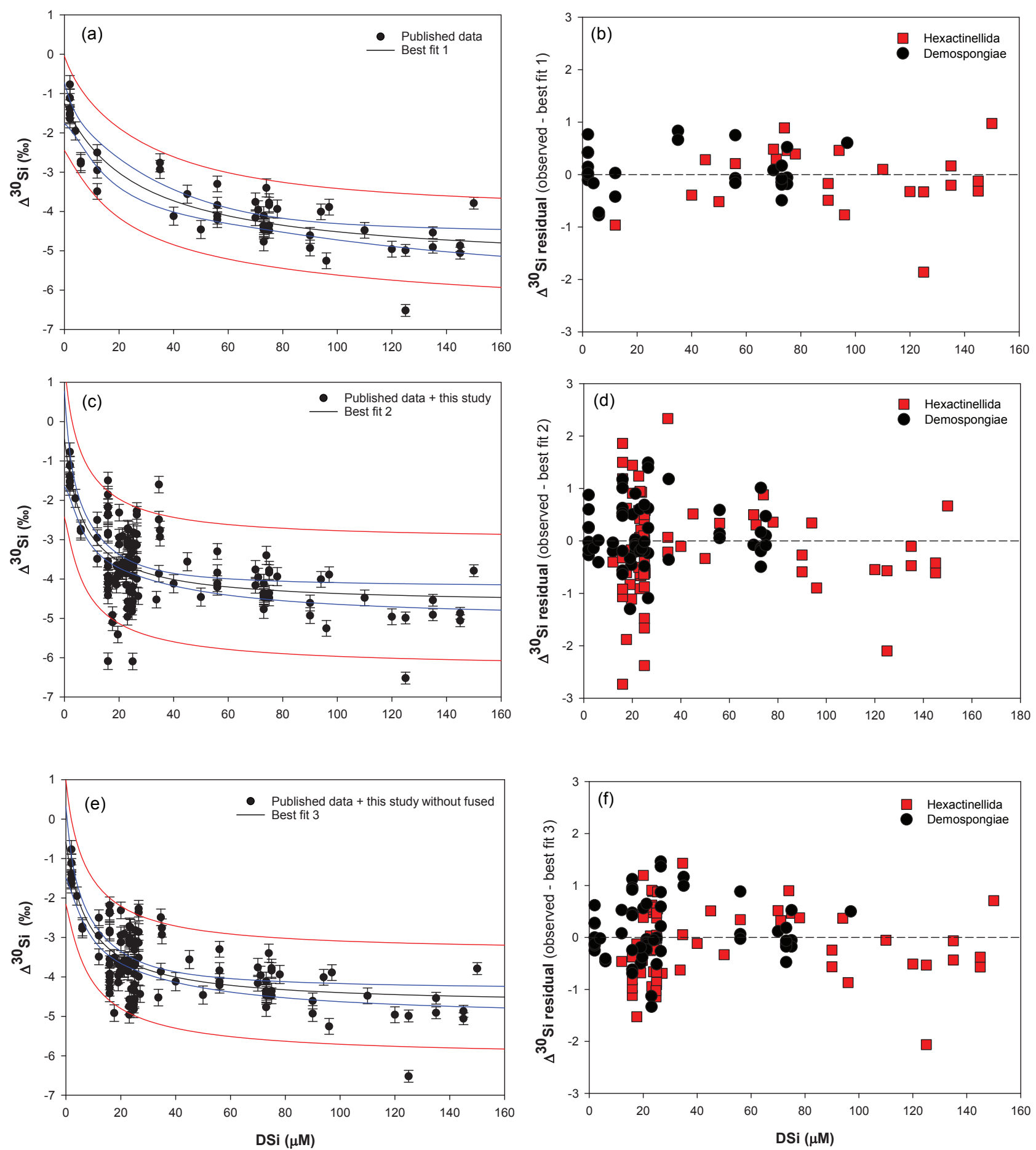

Figure 5. Plots of the best-fit model (left) and the corresponding $\delta^{30} \mathrm{Si}$ residual (right) of Hexactinellida (red squares) and Demospongiae (black circles). (a) Best fit $\left(\delta^{30} \mathrm{Si}=-5.39(0.4)+111.51(11.3) /(26.87(11.2)+\mathrm{DSi})\right)$ and (b) residual from Hendry and Robinson (2012), Wille et al. (2010), and Hendry et al. (2010) data. (c) Best fit $\left(\delta^{30} \mathrm{Si}=-4.69(0.2)+30.89(2.7) /(7.29(2.7)+\mathrm{DSi})\right)$ and (d) residual from Hendry and Robinson (2012), Wille et al. (2010), and Hendry et al. (2010) with the equatorial Atlantic data (JC094). (e) Best fit $\left(\delta^{30} \mathrm{Si}=-4.71(0.18)+34.25(2.6) /(8.29(2.6)+\mathrm{DSi})\right)$ and (f) residual from Hendry and Robinson (2012), Wille et al. (2010), and Hendry et al. (2010) with the equatorial Atlantic (JC094) without the fused spicules (F2 to F5). For best-fit model plots, black lines show the best-fit regression, blue lines the $95 \%$ confidence interval and red lines the $95 \%$ prediction interval, and for the best-fit equation, the numbers in parentheses are the standard error. NB, best fits 2 and 3 and their corresponding residual tests were calculated only with identified sponge samples, which results in discrepancies between Figs. $2 \mathrm{~b}$ and 6 . 
idea that the organic content inside the spicule itself could impact the fractionation of $\mathrm{Si}$ isotopes during biosilicification.

A spicule is composed of hydrated amorphous silica $\left(\mathrm{SiO}_{2}\right)_{2-5}: \mathrm{H}_{2} \mathrm{O}$ with $\mathrm{Si}$ and $\mathrm{O}$ up to $75 \%$ and more, and $6 \%-13 \%$ of water, with some traces of other elements (Sandford, 2003; Schröder et al., 2008) and organic molecules (Uriz et al., 2003). Biosilicification is mediated by enzymes such as silicatein during the formation of the spicule, during which silica layers are deposited around an organic axial filament containing the mature silicatein (Cha et al., 1999; Müller et al., 2008; Wang et al., 2012a). The spicule formation starts with an immature spicule inside a sclerocyte, and $\mathrm{Si}$ is supplied by internal vesicules, the silicasomes. The immature spicule is extruded by evagination from the sclerocyte, resulting in an axial elongation. In the extracellular space the elongated immature spicule is in contact with silicatein and galectin (protein with structural function), which mediate the deposition of silica released from external silicasome vesicules (Müller et al., 2013). One major difference between hexactinellids and demosponges is that the spicules in demosponges fuse their silica and organic layers, constituting the primary spicule, when extruded from the sclerocyte (Müller et al., 2008; Wang et al., 2011; Wang et al., 2012a) while the concentric silica layers could remain separated with thin organic layers in hexactinellids (Aizenberg, 2005; Müller et al., 2009; Wang et al., 2012b).

Thermal analysis showed that the hexactinellid Scolymastra joubini spicules are composed of $15 \%$ OM compared to demosponges with $10 \%$ (Croce et al., 2004). Furthermore, SDS-PAGE analysis of Hexactinellid Euplectella aspergillum has shown that the proteins of its axial filament have higher molecular weights than those isolated in demosponges (Weaver and Morse, 2003), which supports the difference in organic content between the two classes. The larger $\mathrm{Si}$ isotopic fractionation of sponges with a dictyonal framework could be a result of a much greater number of organosilicon complexes within the structure. Indeed, Weaver et al. (2007) showed using a SEM that the internal skeletal structure of the hexactinellid sponge E. aspergillum is comprised of small spicules that are embedded in a silica matrix surrounding a larger spicule (Fig. B1a, in the Appendix). The structural dictyonal framework consists then of multiple layers of silica-organic composite (Fig. B1c and d).

Nevertheless, results from the residual tests (Fig. 5) show that there is no significant difference in $\delta^{30} \mathrm{Si}$ between Hexactinellida and Demospongiae despite the difference in their spicule composition. This suggests that the large $\delta^{30} \mathrm{Si}$ value in sponges that display a dictyonal framework is not solely a result of the differences in organic composition of the spicules but could also be controlled by the enzymes that mediate silica deposition.

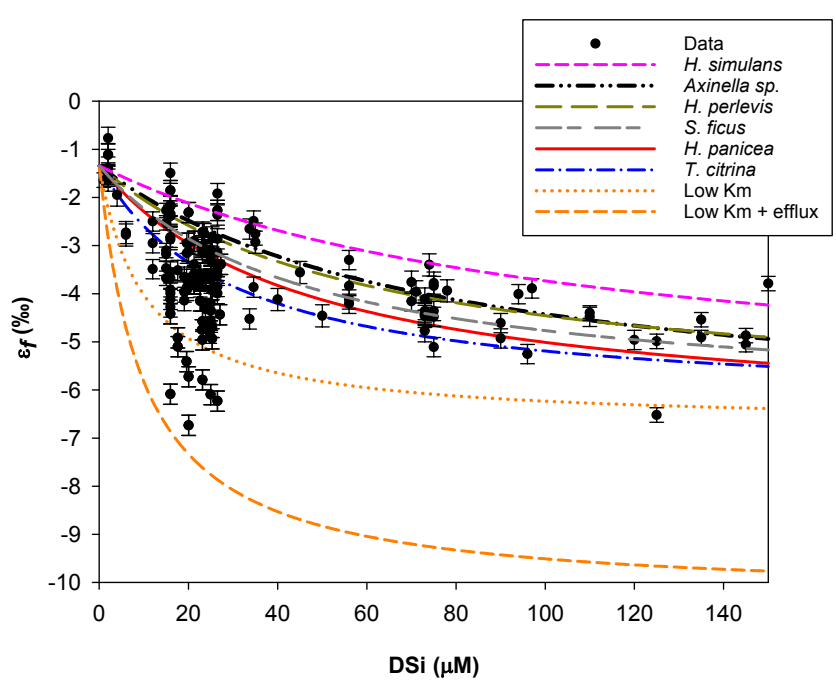

Figure 6. Michaelis-Menten kinetic model of Si isotopic fractionation (Eq. 2) for six parameterisations (see Table 2). Black circles are all previously published and JC094 data. Sponge species from top to bottom are as follows. Pink: $\varepsilon_{\mathrm{f}}$ from Haliclona simulans kinetic parameters (López-Acosta et al., 2018); black: $\varepsilon_{\mathrm{f}}$ from $A x$ inella sp. (Maldonado et al., 2011); green: $\varepsilon_{\mathrm{f}}$ from Hymeniacidon perlevis (López-Acosta et al., 2016); grey: $\varepsilon_{\mathrm{f}}$ from Suberites ficus (López-Acosta et al., 2018); red: $\varepsilon_{\mathrm{f}}$ from Halichondria panicea (Reincke and Barthel, 1997); blue: $\varepsilon_{\mathrm{f}}$ from Tethya citrina (LópezAcosta et al., 2016). The following curves are experimental tests. Orange: $V_{\max , p}$ of López-Acosta et al. (2016) $T$. citrina sp. and $K_{\mathrm{m}}$ $(10 \mu \mathrm{M})$, with $\varepsilon_{E}$ as 1.39 (dotted) or $5 \%$ (dashed).

\subsection{An enzymatic control of $\delta^{30} \mathrm{Si}$ ?}

The second hypothesis relates to the growth rate kinetics of the sponges. As proposed by Wille et al. (2010) the fractionation of $\mathrm{Si}$ isotopes by sponges, $\varepsilon_{\mathrm{f}}$, can be expressed by Eq. (2). The Si isotopic fractionation by sponges is assumed to occur during Si uptake and during internal spicule formation with spicule formation being a function of $\mathrm{Si}$ influx and efflux from the sclerocyte (Milligan et al., 2004). The efflux is the difference between $\mathrm{Si}$ incorporated into the sclerocyte and $\mathrm{Si}$ used to form the spicule (i.e. polymerisation) (Wille et al., 2010, and references therein). To date, only Reincke and Barthel (1997), Maldonado et al. (2011), López-Acosta et al. (2016), and López-Acosta et al. (2018) have cultured sponges to investigate the Michaelis-Menten enzyme kinetics of sponges. In this section, $\varepsilon_{\mathrm{f}}$ has been modelled using $K_{\mathrm{m}, \mathrm{P}}$ and $V_{\max , \mathrm{p}}$ values from these four sponge culture experiments, which summarised in Table 2.

In order to compare the effect of the kinetic parameters on $\mathrm{Si}$ isotopic fractionation following the Wille et al. (2010) model (Eq. 2), the six simulations have been undertaken with a constant value for $\varepsilon_{\mathrm{p}}-\varepsilon_{\mathrm{E}}$ corresponding to $-5.39 \%$ o. $\varepsilon_{\mathrm{p}}-$ $\varepsilon_{\mathrm{E}}$ was calculated from the hyperbolic relationship between DSi and $\delta^{30} \mathrm{Si}$ following Eq. (3) for each sponge species from the culture studies. $V_{\max , \mathrm{I}}$ and $\varepsilon_{\mathrm{tI}}$ are the constant val- 
Table 2. Summary of Michaelis-Menten enzyme kinetic parameters of sponges used to model $\varepsilon_{\mathrm{f}}$ (Fig. 6) following Eq. (2) with $V_{\text {max,p }}$ the the maximum polymerisation rates and $K_{\mathrm{m}, \mathrm{P}}$ the half saturation constant of polymerisation.

\begin{tabular}{lrrl}
\hline Species & $\begin{array}{r}V_{\text {max,p }} \\
\left(\mu \mathrm{mol} \mathrm{Si} \mathrm{h}{ }^{-1} \mathrm{~g}^{-1}\right)\end{array}$ & $\begin{array}{r}K_{\mathrm{m}, \mathrm{P}} \\
(\mu \mathrm{M})\end{array}$ & Reference \\
\hline Haliclona simulans & 0.39 & 108.23 & López-Acosta et al. (2018) \\
Axinella sp. & 1.74 & 74.478 & Maldonado et al. (2011) \\
Hymeniacidon perlevis & 0.127 & 60.441 & López-Acosta et al. (2016) \\
Suberites ficus & 0.0148 & 45.92 & López-Acosta et al. (2018) \\
Halichondria panicea & 19.33 & 45.438 & Reincke and Barthel (1997) \\
Tethya citrina & 0.21 & 29.839 & López-Acosta et al. (2016) \\
\hline
\end{tabular}

ues defined by the minimum misfit function described in Wille et al. (2010), with $V_{\max , \mathrm{I}}=120 \mu \mathrm{mol} \mathrm{Si} \mathrm{h}{ }^{-1} \mathrm{~g}^{-1}$ and $\varepsilon_{\mathrm{tI}}=-1.34 \%$.

Figure 6 shows the results of $\varepsilon_{\mathrm{f}}$ simulated from the six kinetic parameters detailed above and in Table 2. The results of this simulation show lighter $\varepsilon_{\mathrm{f}}$ from Haliclona simulans to Tethya citrina. This observation coincides with the $K_{\mathrm{m}, \mathrm{P}}$ values of each species for which $K_{\mathrm{m}, \mathrm{P}}$ of Haliclona simulans is the highest and $K_{\mathrm{m}, \mathrm{P}}$ of Tethya citrina is the smallest (Table 2). The $K_{\mathrm{m}, \mathrm{P}}$ value illustrates the affinity of an enzyme with a substrate; i.e. the smaller the $K_{\mathrm{m}, \mathrm{P}}$ value, the higher the affinity between the substrate (DSi) concentration and the enzyme. In other words, $K_{\mathrm{m}, \mathrm{P}}$ informs on the binding efficiency between the substrate and the enzyme sites and is used as an indicator of competitiveness among species. The comparison of the six species suggests that the lower the $K_{\mathrm{m}, \mathrm{P}}$, the larger the $\varepsilon_{\mathrm{f}}$ and $\varepsilon_{\mathrm{f}}$ values calculated from LópezAcosta et al. (2016). T. citrina sp. is related to Tethya citrina sp., which has the lowest $K_{\mathrm{m}, \mathrm{P}}$ value, showing a high affinity for DSi compared to the five other species. Unfortunately, to date there are no published culture studies related to the class Hexactinellida but it is likely that their $K_{\mathrm{m}, \mathrm{P}}$ values show a higher affinity with DSi due to their high requirements for silicon.

In López-Acosta et al. (2016), Tethya citrina is more silicified than Hymeniacidon perlevis and has a 2 times higher $V_{\text {max,p }}$ and 3 times lower $K_{\mathrm{m}, \mathrm{P}}$. Dictyonal frameworks display very dense skeletons compared to the demosponges made of loose spicules. Here, the hypothesis made is that the affinity between the enzyme and DSi is higher for sponges with a dictyonal framework, which means that their $K_{\mathrm{m}, \mathrm{P}}$ value is likely to be lower. The simulation of $\mathrm{Si}$ isotopic fractionation has been made using the T. citrina sp. kinetic parameters, except $K_{\mathrm{m}, \mathrm{P}}$, which has been reduced to $10 \mu \mathrm{M}$. Results of this simulation are referred to as low $K_{\mathrm{m}}$ in Fig. 6 . It is clear that the reduction of the half saturation constant $\left(K_{\mathrm{m}, \mathrm{P}}\right)$ value has a major impact on the $\mathrm{Si}$ isotopic fractionation, with larger $\mathrm{Si}$ isotopic fractionation specifically for the low concentration, for which DSi $=20-30 \mu \mathrm{M}$ (Fig. 6). However, the very large $\delta^{30} \mathrm{Si}$ of $-6.74 \%$ ofor $\mathrm{DSi}=20.05 \mu \mathrm{M}$ could be modelled by decreasing $K_{\mathrm{m}, \mathrm{P}}$ to $1 \mu \mathrm{M}$. Whilst this value of $K_{\mathrm{m}, \mathrm{P}}$ is low, and potentially not biologically plausible, more research is required in order to constrain enzymatic control in hexactinellid biomineralisation. However, a low $K_{\mathrm{m}}$ value suggests that the sponges need only a small amount of substrate (DSi) to grow, which means that sponges with a low $K_{\mathrm{m}}$ are likely to grow in seawater with a low DSi concentration. When plotted against depth, the dictyonal framework skeletons, level F5, are located between 1100 and $1800 \mathrm{~m}$ (see Fig. 7) corresponding to a regional minimum in DSi concentration as shown in Figs. $1 \mathrm{~b}$ and $7 \mathrm{~b}$. This observation reinforces the hypothesis that the kinetic parameter $K_{\mathrm{m}, \mathrm{P}}$ is involved in $\mathrm{Si}$ isotopic fractionation. However, to successfully model the highest $\delta^{30} \mathrm{Si}(-6.74 \%$ ) we must also investigate the potential impact of efflux on $\mathrm{Si}$ isotopic fractionation.

Biosilicification in sponges results in the condensation of DSi into BSi controlled by silicifying enzymes, such as silicatein (Cha et al., 1999; Müller et al., 2008), which interacts with other enzymes and proteins, for example galectin and collagen (Krasko et al., 2000; Müller et al., 2013), to form their spicule. The bonding reactions made by silicatein during spicule formation appear to be reversible. For example, the spicule formation of the Demospongiae Suberites domuncula and Geodia cydonium is the result of anabolic reactions (bonds being created) via silicatein and catabolic reactions (breaking of bonds) via silicase (Müller et al., 2008). This dynamic feedback regulates the internal cell DSi concentration (Wang et al., 2012b), which could suggest that the efflux from the sclerocyte is more important than previously thought. To test this hypothesis, $\varepsilon_{\mathrm{f}}$ has been simulated with $K_{\mathrm{m}}=10 \mu \mathrm{M}$ (same as low $K_{\mathrm{m}, \mathrm{P}}$ presented earlier) and by increasing the $\delta^{30} \mathrm{Si}$ fractionation from the efflux of Si from the sclerocyte, $\varepsilon_{E}$, to $5 \%$. The result presented in Fig. 6 (referred to as low $K_{\mathrm{m}}+$ efflux) shows that the largest observed $\delta^{30} \mathrm{Si}$ value of $-6.74 \%$ can be modelled by increasing $\varepsilon_{E}$. Our results highlight the possibility that sponges that grow in a low-DSi environment are "tuned" to take up DSi rapidly into their sclerocytes, releasing any excess via efflux processes. Whilst further work is required to understand sponge biomineralisation, our results show the potential for $\mathrm{Si}$ iso- 


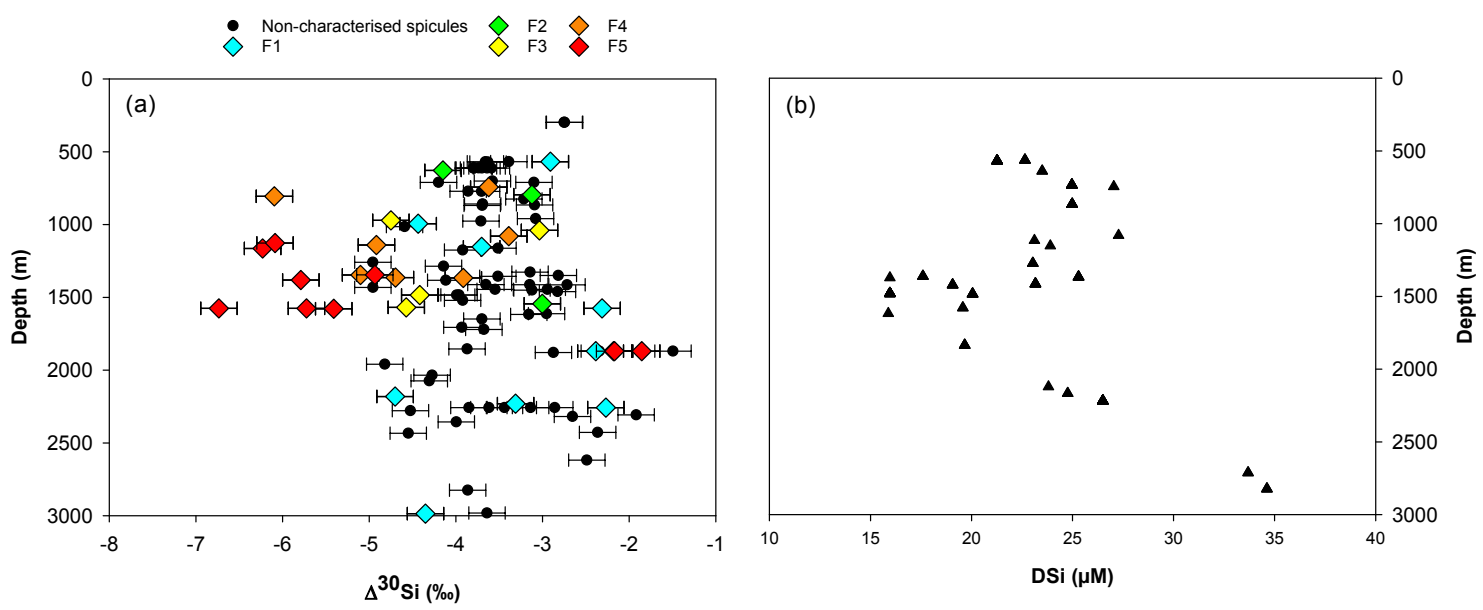

Figure 7. (a) Apparent $\mathrm{Si}$ isotopic fractionation $\left(\delta^{30} \mathrm{Si}\right)$ by sponges against depth from this study. Coloured diamonds represent the degree of fusion from loose spicules (blue), net-like (green), additional silica coating (yellow), dictyonal framework (orange) and dense dictyonal framework (red). (b) DSi concentration in the equatorial Atlantic from EBA, EBB, VEM, VAY and GRM.

topes as a tool to investigate cellular uptake and silicification processes.

\subsection{Comparison with previous studies}

The new data set of this study shows a wide range of $\delta^{30} \mathrm{Si}$ values for a small range of DSi concentrations compared to previous studies (Fig. 2) (Hendry and Robinson, 2012; Wille et al., 2010; Hendry et al., 2010). Here spicule shape, in particular the fusion stage, and $\delta^{30} \mathrm{Si}$ have been investigated and are closely related, and high fusion stages show very large $\delta^{30} \mathrm{Si}$ values, which deviate from the existing calibration. Why has this relationship between spicule fusion and ${ }^{30} \mathrm{Si}$ not been observed in previous studies? This new data set is composed of 103 samples of which 15 deviate from the calibration and display a dictyonal skeleton. Previous studies are based on fewer samples and all the hexactinellid specimens have been found, except for one, in high-DSi environments (higher than $45 \mu \mathrm{M}$ ) (Hendry and Robinson, 2012; Wille et al., 2010; Hendry et al., 2010). As the spicules in Hexactinellida can be loose, partially or totally fused, or even cemented by secondary silica (Uriz et al., 2003), it is likely that previous studies only analysed samples with loose spicules (equivalent to F1 here). Furthermore, Hendry and Robinson (2012) published one sample with $\delta^{30} \mathrm{Si}=-6.52 \%$ o for $\mathrm{DSi}=125 \mu \mathrm{M}$ (Fig. 2). This sample also displayed a fused skeleton but at this date the large fractionation was attributed to the lack of constraint on ambient seawater $\delta^{30} \mathrm{Si}$.

\section{Conclusions}

Marine sponges are potential geochemical archives of present and past oceanic silicon cycling. Through a simple kinetic model it is possible to predict $\delta^{30} \mathrm{Si}$ fractionation of modern sponges, which support the use of Si isotopes in the reconstruction of past silicic acid concentration of bottom waters. However, the data presented here illustrate that the proxy has its limits. The skeleton type and, in particular, the level of fusion of the skeleton lattice impacts the $\mathrm{Si}$ isotopic fractionation significantly. Sponges displaying a dictyonal framework do not fit the asymptotic relationship with DSi observed in previous studies. This divergence has also been observed for a carnivorous sponge (Hendry et al., 2015 ) for which it is suggested that the Si isotopic fractionation is associated with a specific hypersilicified spicule type (desma). Here, we suggest that the organic template responsible for spicule formation, the organic matter content that differs between the two major classes, could influence the $\mathrm{Si}$ isotopic fractionation. However, residual tests have shown that there is no significant difference between Hexactinellida and Demospongiae when differences in habitat and nutrient conditions are taken into consideration. Yet, this study shows a strong relationship between enzyme kinetic parameters $\left(K_{\mathrm{m}}\right)$ and $\varepsilon_{\mathrm{f}}$, with low $K_{\mathrm{m}}$ related to lighter $\mathrm{Si}$ isotopic fractionation, which suggests that $\mathrm{Si}$ isotopic fractionation is dependent on the equilibrium between molecules and bonding interactions mediated by catabolic and anabolic reactions in the process of biomineralisation. As yet, sponge biomineralisation processes are not fully understood and further work is required to understand the specific pathways involved, especially in the case of the hexactinellids.

Data availability. The data that support the findings of this study are available from the corresponding author, L. Cassarino, upon reasonable request. 
Appendix A

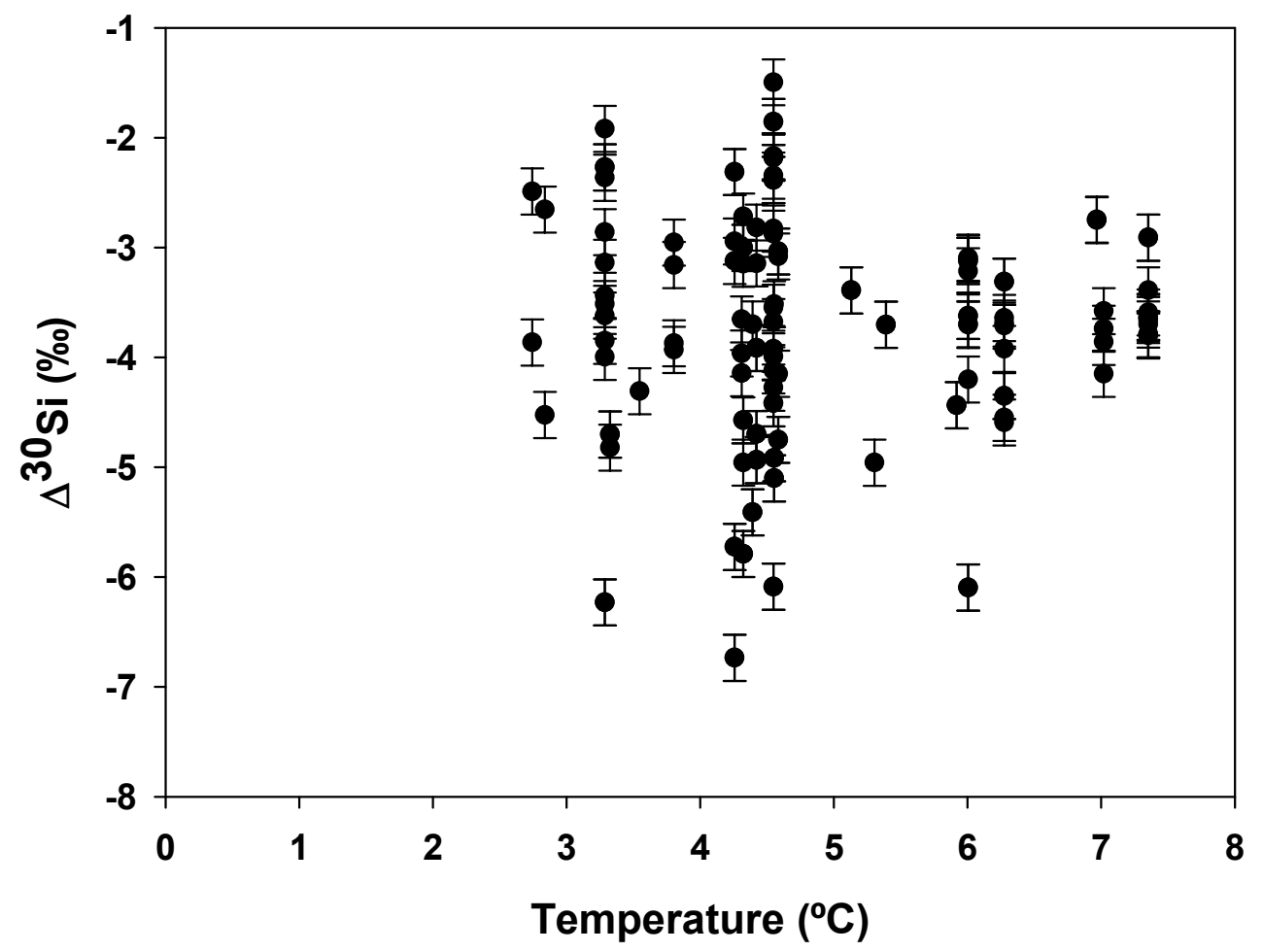

Figure A1. Apparent Si isotopic fractionation $\left(\delta^{30} \mathrm{Si}\right)$ of deep sea sponges from the equatorial Atlantic against the ambient seawater temperature. 
Table A1. Location details and isotopic signature $\left(\delta^{30} \mathrm{Si}\right)$ and apparent $\mathrm{Si}$ isotopic fractionation $\left(\delta^{30} \mathrm{Si}\right)$ of deep sea sponges from the equatorial Atlantic. Taxonomic rank of sample starts with the class (Hexact. for Hexactinellida and Demosp. for Demospongiae), the order and finally the family. $\delta^{30} \mathrm{Si}_{\text {spicule }}$ and $\delta^{29} \mathrm{Si}_{\text {spicule }}$ are the $\mathrm{Si}$ isotopic signatures of the spicules, $\delta^{30} \mathrm{Si}$ DSi is the $\mathrm{Si}$ isotopic signature of seawater, $\delta^{30} \mathrm{Si}$ is the apparent $\mathrm{Si}$ isotopic fractionation by deep sea sponges and fusion is the fusion stage defined from SEM images (see Table 1 for details). Reproducibility, 2 SD, is based upon measurements of standards (see Sect. 2.3) and corresponds to $0.13 \%$ for $\delta^{30} \mathrm{Si}_{\text {spicule }}, 0.11 \%$ or for $\delta^{30} \mathrm{Si}_{\mathrm{DSi}}$ and $0.17 \%$ o for $\delta^{30} \mathrm{Si}$.

\begin{tabular}{|c|c|c|c|c|c|c|c|c|c|c|}
\hline Loc. & $\begin{array}{l}\text { Lat } \\
(\mathrm{N})\end{array}$ & $\begin{array}{r}\text { Long } \\
(\mathrm{W})\end{array}$ & $\begin{array}{r}\text { Depth } \\
(\mathrm{m})\end{array}$ & $\begin{array}{r}\text { DSi } \\
(\mu \mathrm{M})\end{array}$ & Class. Order. Family & $\begin{array}{r}\delta^{30} \mathrm{Si}_{\text {spicule }} \\
(\% o)\end{array}$ & $\begin{array}{r}\delta^{29} \mathrm{Si}_{\text {spicule }} \\
(\% o)\end{array}$ & $\begin{array}{r}\delta^{30} \mathrm{Si}_{\mathrm{DSi}} \\
(\% o)\end{array}$ & $\begin{array}{r}\delta^{30} \mathrm{Si} \\
(\% \circ)\end{array}$ & Fusion \\
\hline EBA & 9.2358 & 21.5667 & 994 & 27.04 & Hexact. & -3.19 & -1.54 & 1.24 & -4.44 & $\mathrm{~F} 1$ \\
\hline EBA & 9.4686 & 21.5686 & 1079 & 27.28 & & -2.20 & -1.10 & 1.19 & -3.39 & F4 \\
\hline EBA & 10.1172 & 22.2717 & 298 & 23.5 & Hexact. & -1.36 & -0.74 & 1.39 & -2.75 & \\
\hline EBA & 10.1172 & 22.2717 & 298 & 23.5 & Hexact. & -1.43 & -0.71 & 1.32 & -2.75 & \\
\hline EBA & 9.2064 & 21.2861 & 2073 & 23.81 & $\begin{array}{l}\text { Hexact. } \\
\text { Lyssacinosida. } \\
\text { Euplectellidae }\end{array}$ & -3.29 & -1.66 & 1.02 & -4.31 & \\
\hline EBA & 10.1517 & 23.6956 & 1413 & 23.16 & Hexact. & -1.97 & -1.01 & 1.18 & -3.15 & \\
\hline EBA & 10.1517 & 23.6956 & 1414 & 23.16 & Hexact. & -1.54 & -0.77 & 1.18 & -2.72 & \\
\hline EBA & 9.7811 & 23.0761 & 1569 & 23.16 & $\begin{array}{l}\text { Hexact. } \\
\text { Lyssacinosida. } \\
\text { Euplectellidae }\end{array}$ & -3.40 & -1.61 & 1.17 & -4.57 & F3 \\
\hline EBA & 10.1317 & 23.6344 & 1431 & 23.16 & & -3.78 & -1.90 & 1.18 & -4.96 & \\
\hline EBA & 10.2072 & 23.7558 & 1381 & 23.16 & & -4.61 & -2.31 & 1.18 & -5.79 & F5 \\
\hline $\begin{array}{l}\text { EBA } \\
\text { EBA }\end{array}$ & 9.6356 & 22.8825 & 1544 & 23.16 & $\begin{array}{l}\text { Hexact. } \\
\text { Hexact. } \\
\text { Sceptrulophora } \\
\text { Sceptrulophora } \\
\text { incertae sedis }\end{array}$ & $\begin{array}{l}-1.83 \\
-3.41\end{array}$ & $\begin{array}{l}-0.97 \\
-1.83\end{array}$ & 1.18 & -3.00 & $\begin{array}{l}\mathrm{F} 2 \\
\mathrm{~F} 4\end{array}$ \\
\hline EBA & 11.6844 & 22.6069 & 2278 & 33.69 & $\begin{array}{l}\text { Hexact. } \\
\text { Euplectellidae }\end{array}$ & -3.32 & -1.66 & 1.20 & -4.52 & \\
\hline EBA & 10.3311 & 23.4453 & 2318 & 33.69 & $\begin{array}{l}\text { Hexact. } \\
\text { Amphidiscosida } \\
\text { Hyalonematidae }\end{array}$ & -1.45 & -0.72 & 1.20 & -2.65 & \\
\hline EBA & 10.1939 & 23.8964 & 1326 & 25.3 & $\begin{array}{l}\text { Hexact. } \\
\text { Euplectellidae }\end{array}$ & -1.97 & -0.98 & 1.18 & -3.14 & \\
\hline EBA & 10.3692 & 24.0494 & 1366 & 25.3 & & -2.74 & -1.39 & 1.18 & -3.91 & $\mathrm{~F} 4$ \\
\hline EBA & 9.2089 & 21.3092 & 1350 & 25.3 & Hexact. & -1.64 & -0.81 & 1.18 & -2.82 & \\
\hline EBA & 9.2089 & 21.3092 & 1364 & 25.3 & & -3.52 & -1.77 & 1.18 & -4.70 & $\mathrm{~F} 4$ \\
\hline EBA & 9.2092 & 21.3092 & 1345 & 25.3 & & -4.18 & -2.21 & 1.18 & -4.94 & F5 \\
\hline EBB & 5.6133 & 26.9689 & 1575 & 20.05 & Hexact. & -1.09 & -0.59 & 1.23 & -2.31 & $\mathrm{~F} 1$ \\
\hline EBB & 5.6133 & 26.9689 & 1575 & 20.05 & & -5.51 & -2.71 & 1.23 & -6.74 & F5 \\
\hline EBB & 5.6133 & 26.9689 & 1575 & 20.05 & & -4.50 & -2.14 & 1.23 & -5.73 & F5 \\
\hline EBB & 7.9467 & 28.5336 & 1445 & 20.05 & $\begin{array}{l}\text { Demosp. } \\
\text { Tetractinellida. } \\
\text { Geodiidae }\end{array}$ & -1.72 & -0.83 & 1.23 & -2.95 & \\
\hline EBB & 7.3364 & 28.5236 & 628 & 22.64 & $\begin{array}{l}\text { Hexact. } \\
\text { Sceptrulophora. } \\
\text { Farreidae }\end{array}$ & -2.95 & -1.51 & 1.20 & -4.15 & $\mathrm{~F} 2$ \\
\hline EBB & 7.2889 & 28.8436 & 701 & 22.64 & $\begin{array}{l}\text { Demosp. } \\
\text { Tetractinellida. } \\
\text { Vulcanellidae }\end{array}$ & -2.38 & -1.23 & 1.20 & -3.58 & \\
\hline EBB & 7.0161 & 28.2778 & 971 & 23.03 & Demosp. Mycalidae? & -3.50 & -1.80 & 1.25 & -4.75 & F3 \\
\hline EBB & 6.6592 & 26.9619 & 959 & 23.03 & $\begin{array}{l}\text { Hexact. } \\
\text { Lyssacinosida. } \\
\text { Euplectellidae }\end{array}$ & -1.83 & -0.97 & 1.25 & -3.08 & \\
\hline EBB & 7.3292 & 28.3714 & 611 & 22.64 & & -2.54 & -1.30 & 1.20 & -3.74 & \\
\hline EBB & 7.2764 & 29.3858 & 771 & 22.64 & Hexact. & -2.66 & -1.37 & 1.20 & -3.86 & \\
\hline EBB & 7.5686 & 28.2811 & 2257 & 26.5 & & -2.42 & -1.35 & 1.20 & -3.62 & \\
\hline
\end{tabular}


Table A1. Continued.

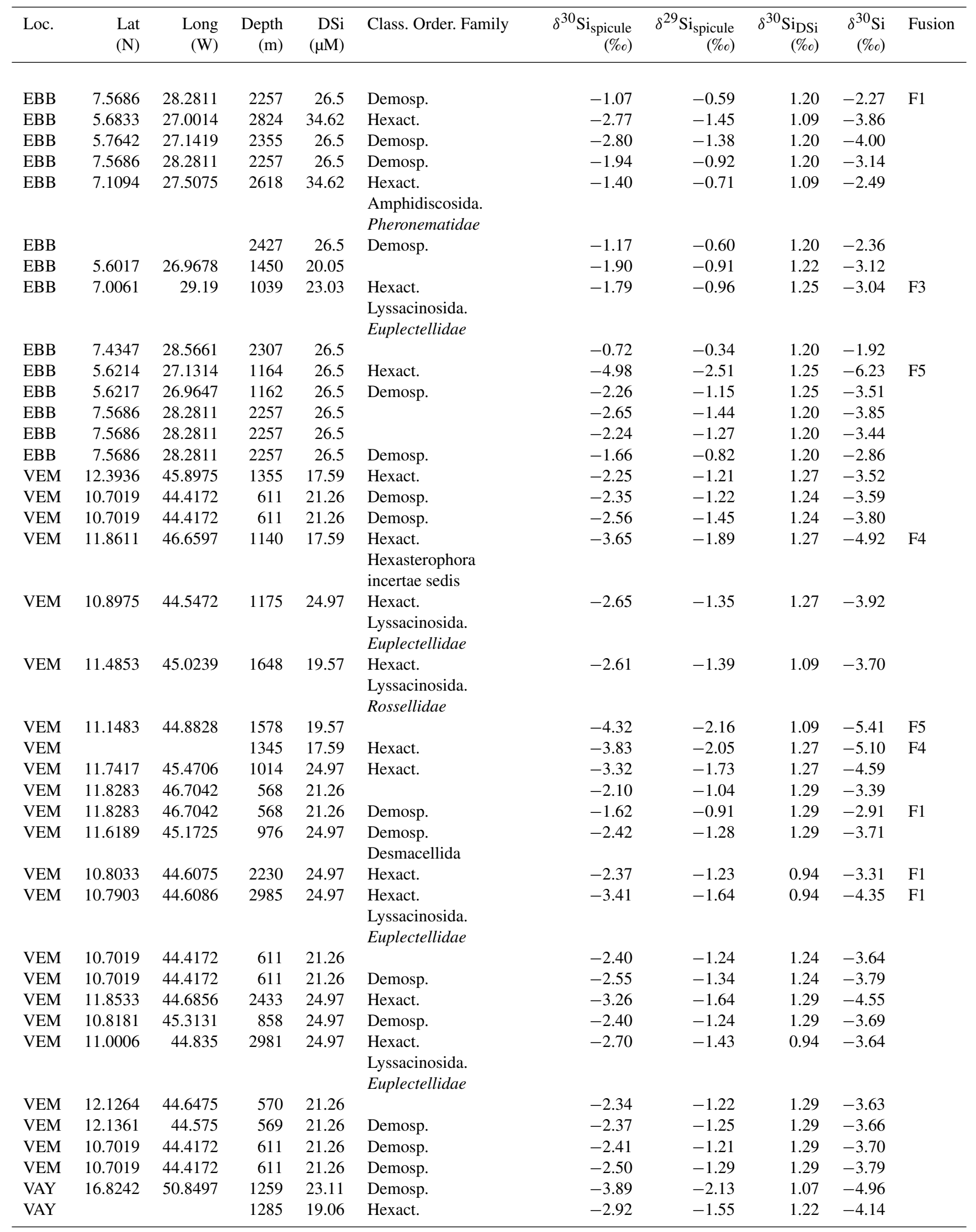


Table A1. Continued.

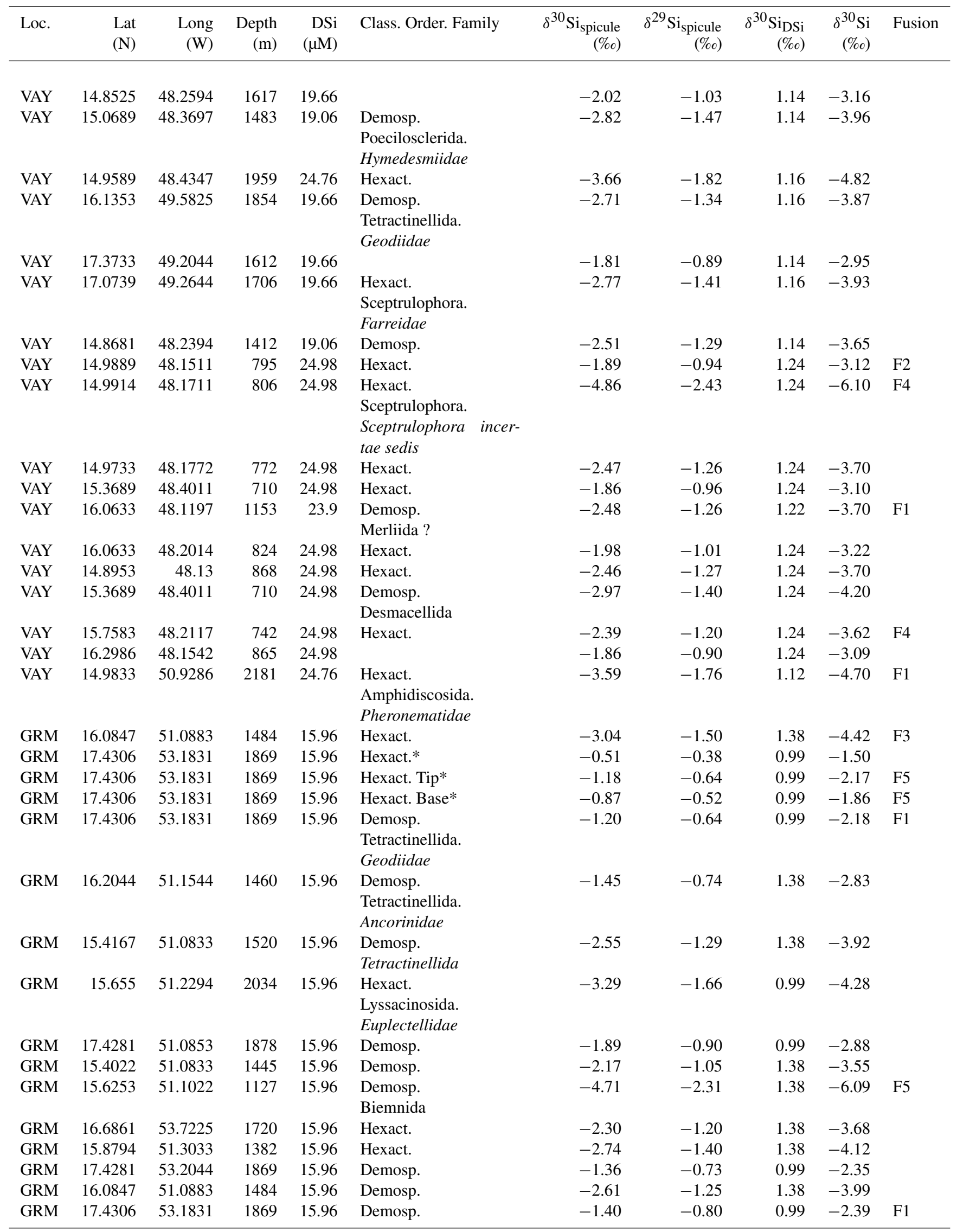




\section{Appendix B}
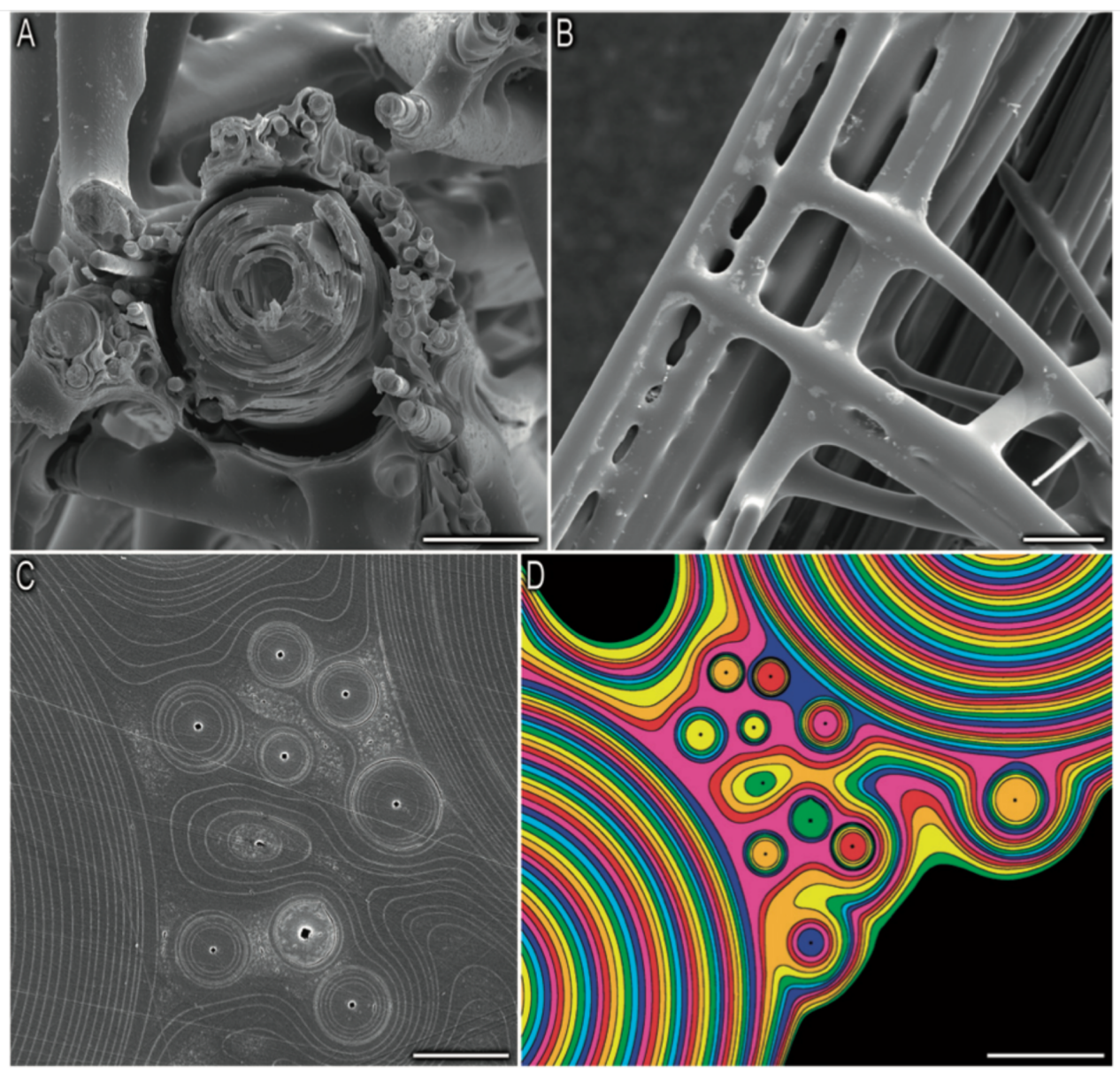

Figure B1. Picture from Weaver et al. (2007). Organisational details of the consolidation silica matrix. (a) Cross section of the skeletal lattice showing a large spicule surrounded by small spicules, scale bar: $50 \mu \mathrm{m}$. (b) External view of the skeletal lattice, scale bar: $100 \mu \mathrm{m}$. Panels (c) and (d) show a polished cross section showing that the cement of the skeletal lattice is made of multiple layers, scale bar: 10 and $20 \mu \mathrm{m}$ respectively. 
Sample availability. Samples and sample images are available at the University of Bristol; for further detail contact Katharine R. Hendry, email address: k.hendry@bristol.ac.uk

Author contributions. LC conducted the analysis, created the figures and wrote the paper. CDC helped conduct the isotopic analysis. KRH conducted the fieldwork and conceived the study. JRX identified the samples. All authors have reviewed the paper.

Competing interests. The authors declare that they have no conflict of interest.

Acknowledgements. We acknowledge the science team and the crew of JC094 and Laura Robinson for cruise organisation. We would also like to thank Paul Curnow for constructive comments, Stuart Kearns for his SEM training and assistance, and Maria López-Acosta for her help. Finally, the funding from the Royal Society (grant code RG130386) and from the European Research Council is acknowledged. Joana R. Xavier received support from the European Union's Horizon 2020 research and innovation program through the SponGES project (grant agreement no. 679849).

Edited by: Jack Middelburg

Reviewed by: Jill Sutton and two anonymous referees

\section{References}

Aizenberg, J.: Skeleton of Euplectella sp.: Structural Hierarchy from the Nanoscale to the Macroscale, Science, 309, 275-278, https://doi.org/10.1126/science.1112255, 2005.

Antcliffe, J. B., Callow, R. H., and Brasier, M. D.: Giving the early fossil record of sponges a squeeze, Biol. Rev., 89, 972-1004, https://doi.org/10.1111/brv.12090, 2014.

Cardinal, D., Alleman, L. Y., de Jong, J., Ziegler, K., and Andre, L.: Isotopic composition of silicon measured by multicollector plasma source mass spectrometry in dry plasma mode, J. Anal. Atom. Spectrom., 18, 213-218, https://doi.org/10.1039/b210109b, 2003.

Cardinal, D., Savoye, N., Trull, T. W., Dehairs, F., Kopczynska, E. E., Fripiat, F., Tison, J. L., and André, L.: Silicon isotopes in spring Southern Ocean diatoms: Large zonal changes despite homogeneity among size fractions, Mar. Chem., 106, 46-62, https://doi.org/10.1016/j.marchem.2006.04.006, 2007.

Cha, J. N., Shimizu, K., Zhou, Y., Christiansen, S. C., Chmelka, B. F., Stucky, G. D., and Morse, D. E.: Silicatein filaments and subunits from a marine sponge direct the polymerization of silica and silicones in vitro, P. Natl. Acad. Sci. USA, 96, 361-365, https://doi.org/10.1073/pnas.96.2.361, 1999.

Croce, G., Frache, A., Milanesio, M., Marchese, L., Causà, M., Viterbo, D., Barbaglia, A., Bolis, V., Bavestrello, G., Cerrano, C., Benatti, U., Pozzolini, M., Giovine, M., and Amenitsch, H.: Structural Characterization of Siliceous Spicules from Marine Sponges, Biophys. J., 86, 526-534, https://doi.org/10.1016/S0006-3495(04)74131-4, 2004
De Bièvre, P. and Taylor, P. D. P.: Table of the isotopic compositions of the elements, Int. J. Mass Spectrom., 123, 149-166, https://doi.org/10.1016/0168-1176(93)87009-H, 1993.

De La Rocha, C. L.: Silicon isotope fractionation by marine sponges and the reconstruction of the silicon isotope composition of ancient deep water, Geol. Soc. Am. Bull., 31, 423-426, https://doi.org/10.1130/00917613(2003)031<0423:SIFBMS>2.0.CO;2, 2003.

De La Rocha, C. L., Brzezinski, M. A., and DeNiro, M. J.: Fractionation of silicon isotopes by marine diatoms during biogenic silica formation, Geochim. Cosmochim. Ac., 61, 5051-5056, https://doi.org/10.1016/s0016-7037(97)00300-1, 1997.

De La Rocha, C. L., Bescont, P., Croguennoc, A., and Ponzevera, E.: The silicon isotopic composition of surface waters in the Atlantic and Indian sectors of the Southern Ocean, Geochim. Cosmochim. Ac., 75, 5283-5295, https://doi.org/10.1016/j.gca.2011.06.028, 2011.

Ereskovsky, A. V.: Development of Sponges from the Class Hexactinellida Schmidt, 1870, in: The Comparative Embryology of Sponges, Springer, Chap. 2, 37-46, https://doi.org/10.1007/97890-481-8575-7, 2010.

Fontorbe, G., Frings, P. J., De La Rocha, C. L., Hendry, K. R., Carstensen, J., and Conley, D. J.: Enrichment of dissolved silica in the deep equatorial Pacific during the Eocene-Oligocene, Paleoceanography, 32, 848-863, https://doi.org/10.1002/2017PA003090, 2017.

Grasse, P., Brzezinski, M. A., Cardinal, D., de Souza, G. F., Andersson, P. S., Closset, I., Cao, Z., Dai, M., Ehlert, C., Estrade, N., François, R., Frank, M., Jiang, G., Jones, J. L., Kooijman, E., Liu, Q., Lu, D., Pahnke, K., Ponzevera, E., Schmitt, M., Sun, X., Sutton, J. N., Thil, F., Weis, D., Wetzel, F., Zhang, A., Zhang, J., and Zhang, Z.: GEOTRACES inter-calibration of the stable silicon isotope composition of dissolved silicic acid in seawater, J. Anal. At. Spectrom., 32, 562-578, 2017.

He, H.-t., Zhang, S., Zhu, C., and Liu, Y.: Equilibrium and kinetic $\mathrm{Si}$ isotope fractionation factors and their implications for $\mathrm{Si}$ isotope distributions in the Earth's surface environments, Acta Geochimica, 35, 15-24, https://doi.org/10.1007/s11631015-0079-x, 2016.

Hendry, K. R. and Robinson, L. F.: The relationship between silicon isotope fractionation in sponges and silicic acid concentration: Modern and core-top studies of biogenic opal, Geochim. Cosmochim. Ac., 81, 1-12, https://doi.org/10.1016/j.gca.2011.12.010, 2012.

Hendry, K. R., Georg, B. R., Rickaby, R. E. M., Robinson, L. F., and Halliday, A. N.: Deep ocean nutrients during the Last Glacial Maximum deduced from sponge silicon isotopic compositions, Earth Planet. Sc. Lett., 292, 290-300, https://doi.org/10.1016/j.epsl.2010.02.005, 2010.

Hendry, K. R., Leng, M. J., Robinson, L. F., Sloane, H. J., Blusztjan, J., Rickaby, R. E. M., Georg, B. R., and Halliday, A. N.: Silicon isotopes in Antarctic sponges: an interlaboratory comparison, Antarct. Sci., 23, 34-42, 2011.

Hendry, K. R., Swann, G. E. A., Leng, M. J., Sloane, H. J., Goodwin, C., Berman, J., and Maldonado, M.: Technical Note: Silica stable isotopes and silicification in a carnivorous sponge Asbestopluma sp., Biogeosciences, 12, 3489-3498, https://doi.org/10.5194/bg-12-3489-2015, 2015. 
Hendry, K. R., Gong, X., Knorr, G., Pike, J., and Hall, I. R.: Deglacial diatom production in the tropical North Atlantic driven by enhanced silicic acid supply, Earth Planet. Sc. Lett., 438, 122129,2016

Hooper, J. N. a. and Van Soest, R. W.: Systema Porifera. A Guide to the Classification of Sponges, Plenum, 1, 1-1707, https://doi.org/10.1007/978-1-4615-0747-5_1, 2002.

Jochum, K. P., Schuessler, J. A., Wang, X.-H., Stoll, B., Weis, U., Müller, W. E. G., Haug, G. H., Andreae, M. O., and Froelich, P. N.: Whole-Ocean Changes in Silica and Ge/Si Ratios During the Last Deglacial Deduced From Long-Lived Giant Glass Sponges, Geophys. Res. Lett., 44, 11555-11564, 2017.

Karl, D. M. and Tien, G.: Magic: A sensitive and precise method for measuring dissolved phosphorus in aquatic environments, Limnol. Oceanogr., 37, 105-116, https://doi.org/10.4319/1o.1992.37.1.0105, 1992.

Krasko, A., Lorenz, B., Batel, R., Schröder, H. C., Müller, I. M., and Müller, W. E. G.: Expression of silicatein and collagen genes in the marine sponge Suberites domuncula is controlled by silicate and myotrophin, Eur. J. Biochem., 267, 4878-4887, 2000.

Leys, S. P. and Lauzon, N. R.: Hexactinellid sponge ecology: growth rates and seasonality in deep water sponges, J. Exp. Mar. Biol. Ecol., 230, 111-129, https://doi.org/10.1016/S00220981(98)00088-4, 1998

López-Acosta, M., Leynaert, A., and Maldonado, M.: Silicon consumption in two shallow-water sponges with contrasting biological features, Limnol. Oceanogr., 61, 2139-2150, 2016.

López-Acosta, M., Leynaert, A., Grall, J., and Maldonado, M.: Silicon consumption kinetics by marine sponges: An assessment of their role at the ecosystem level, Limnol. Oceanogr., 63, 1-15, https://doi.org/10.1002/lno.10956, 2018.

Love, G. D., Grosjean, E., Stalvies, C., Fike, D. A., Grotzinger, J. P., Bradley, A. S., Kelly, A. E., Bhatia, M., Meredith, W., Snape, C. E., Bowring, S. A., Condon, D. J., and Summons, R. E.: Fossil steroids record the appearance of Demospongiae during the Cryogenian period, Nature, 457, 718-721, 2009.

Maldonado, M. and Riesgo, A.: Intra-epithelial spicules in a homosclerophorid sponge, Cell Tissue Res., 328, 639-650, 2007.

Maldonado, M., Carmona, M. C., Velásquez, Z., Puig, A., Cruzado, A., López, A., and Young, C. M.: Siliceous sponges as a silicon sink: An overlooked aspect of benthopelagic coupling in the marine silicon cycle, Limnol. Oceanogr., 50, 799-809, 2005.

Maldonado, M., Riesgo, A., Bucci, A., and Tzlerb, K. R.: Revisiting silicon budgets at a tropical continental shelf: Silica standing stocks in sponges surpass those in diatoms, Limnol. Oceanogr., 55, 2001-2010, 2010.

Maldonado, M., Navarro, L., Grasa, A., Gonzalez, A., and Vaquerizo, I.: Silicon uptake by sponges: a twist to understanding nutrient cycling on continental margins, Sci. Rep., 1, 1-30, 2011.

Maldonado, M., Ribes, M., and van Duyl, F. C.: Nutrient Fluxes Through Sponges, Adv. Mar. Biol., 62, 113-182, 2012.

Milligan, A. J., Varela, D. E., Brzezinski, M. a., and Morel, F. M. M.: Dynamics of silicon metabolism and silicon isotopic discrimination in a marine diatomas a function of $p \mathrm{CO}_{2}$, Limnol. Oceanogr., 49, 322-329, 2004.

Montanez, I. P.: Biological skeletal carbonate records changes in major-ion chemistry of paleo-oceans, P. Natl. Acad. Sci. USA, 99, 15852-15854, https://doi.org/10.1073/pnas.262659599, 2002.
Müller, W. E. G., Schloßmacher, U., Wang, X., Boreiko, A., Brandt, D., Wolf, S. E., Tremel, W., and Schröder, H. C.: Poly(silicate)metabolizing silicatein in siliceous spicules and silicasomes of demosponges comprises dual enzymatic activities (silica polymerase and silica esterase), FEBS J., 275, 362-370, 2008.

Müller, W. E. G., Wang, X., Burghard, Z., Bill, J., Krasko, A., Boreiko, A., Schloßmacher, U., Schröder, H. C., and Wiens, M.: Biosintering processes in hexactinellid sponges: Fusion of bio-silica in giant basal spicules from Monorhaphis chuni, J. Struct. Biol., 168, 548-561, 2009.

Müller, W. E. G., Schröder, H. C., Burghard, Z., Pisignano, D., and Wang, X.: Silicateins-A Novel Paradigm in Bioinorganic Chemistry: Enzymatic Synthesis of Inorganic Polymeric Silica, Chemistry-Eur. J., 19, 5790-5804, 2013.

Otzen, D.: The Role of Proteins in Biosilicification, Scientifica, 2012, 1-22, 2012.

Pansini, M. and Pronzato, R.: Observation on the dynamics of a mediterranean sponge community, New Perspectives in Sponge Biology, 404-415, 1990.

Ragueneau, O., Gallinari, M., Corrin, L., Grandel, S., Hall, P., Hauvespre, A., Lampitt, R., Rickert, D., Stahl, H., Tengberg, A., and Witbaard, R.: The benthic silica cycle in the Northeast Atlantic: annual mass balance, seasonality, and importance of non-steadystate processes for the early diagenesis of biogenic opal in deepsea sediments, Prog. Oceanogr., 50, 171-200, 2001.

Ragueneau, O., Savoye, N., Del Amo, Y., Cotten, J., Tardiveau, B., and Leynaert, A.: A new method for the measurement of biogenic silica in suspended matter of coastal waters: using $\mathrm{Si}$ :Al ratios to correct for the mineral interference, Cont. Shelf Res., 25, 697710, 2005.

Reincke, T. and Barthel, D.: Silica uptake kinetics of Halichondria panicea in Kiel Bight, Mar. Biol., 129, 591-593, 1997.

Reynolds, B. C., Frank, M., and Halliday, A. N.: Silicon isotope fractionation during nutrient utilization in the North Pacific, Earth Planet. Sc. Lett., 244, 431-443, https://doi.org/10.1016/j.eps1.2006.02.002, 2006.

Reynolds, B. C., Aggarwal, J., André, L., Baxter, D., Beucher, C. P., Brzezinski, M. A., Engström, E., Georg, B. R., Land, M., Leng, M. J., Opfergelt, S., Rodushkin, I., Sloane, H. J., van den Boorn, S. H. J. M., Vroon, P. Z., and Cardinal, D.: An inter-laboratory comparison of $\mathrm{Si}$ isotope reference materials, J. Anal. Atom. Spectrom., 22, 561-568, https://doi.org/10.1039/B616755A, 2007.

Sandford, F.: Physical and chemical analysis of the siliceous skeletons in six sponges of two groups (Demospongiae and Hexactinellida), Microsc. Res. Techniq., 62, 336-355, https://doi.org/10.1002/jemt.10400, 2003.

Schröder, H. C., Wang, X., Tremel, W., Ushijima, H., and Müller, W. E. G.: Biofabrication of biosilica-glass by living organisms, Nat. Prod. Rep., 25, 455-474, 2008.

Steele, R. C., Coath, C. D., Regelous, M., Russell, S., and Elliott, T.: Neutron-poor nickel isotope anomalies in meteorites, Astrophys. J., 758, 1-21, https://doi.org/10.1088/0004637X/758/1/59, 2012.

Strehlow, B. W., Pineda, M.-c., Duckworth, A., Kendrick, G. A., Renton, M., Azmi, M., Wahab, A., Webster, N. S., and Clode, P. L.: Sediment tolerance mechanisms identified in sponges using advanced imaging techniques, PEER J., 5:e3904, 1-26, https://doi.org/10.7717/peerj.3904, 2017. 
Tréguer, P. J. and De La Rocha, C. L.: The World Ocean Silica Cycle, Annu. Rev. Mar. Sci., 5, 477-501, 2013.

Uriz, M.-J.: Mineral skeletogenesis in sponges, Can. J. Zool., 84, 322-356, https://doi.org/10.1139/z06-032, 2006.

Uriz, M.-J., Turon, X., Becerro, M. A., and Agell, G.: Siliceous spicules and skeleton frameworks in sponges: Origin, diversity, ultrastructural patterns, and biological functions, Microsc. Res. Techniq., 62, 279-299, 2003.

Van Soest, R. W., Boury-Esnault, N., Vacelet, J., Dohrmann, M., Erpenbeck, D., De Voogd, N. J., Santodomingo, N., Vanhoorne, B., Kelly, M., and Hooper, J. N.: Global diversity of sponges (Porifera), PLoS ONE, 7, 1-23, https://doi.org/10.1371/journal.pone.0035105, 2012.

Wang, X., Wiens, M., Schroder, H. C., Jochum, K. P., Schlossmacher, U., Gotz, H., Duschner, H., and Muller, W. E. G.: Circumferential spicule growth by pericellular silica deposition in the hexactinellid sponge Monorhaphis chuni, J. Exp. Biol., 214, 2047-2056, 2011.

Wang, X., Schloßmacher, U., Wiens, M., Batel, R., Schröder, H. C., and Müller, W. E. G.: Silicateins, silicatein interactors and cellular interplay in sponge skeletogenesis: formation of glass fiberlike spicules, FEBS J., 279, 1721-1736, 2012a.
Wang, X., Schröder, H. C., Wang, K., Kaandorp, J. A., and Müller, W. E. G.: Genetic, biological and structural hierarchies during sponge spicule formation: from soft sol-gels to solid 3D silica composite structures, Soft Matter, 8, 9489-9714, 2012b.

Weaver, J. C. and Morse, D. E.: Molecular biology of demosponge axial filaments and their roles in biosilicification, Microsc. Res. Techniq., 62, 356-367, 2003.

Weaver, J. C., Aizenberg, J., Fantner, G. E., Kisailus, D., Woesz, A., Allen, P., Fields, K., Porter, M. J., Zok, F. W., Hansma, P. K., Fratzl, P., and Morse, D. E.: Hierarchical assembly of the siliceous skeletal lattice of the hexactinellid sponge Euplectella aspergillum, J. Struct. Biol., 158, 93-106, https://doi.org/10.1016/j.jsb.2006.10.027, 2007.

Wille, M., Sutton, J. N., Ellwood, M. J., Sambridge, M., Maher, W., Eggins, S., and Kelly, M.: Silicon isotopic fractionation in marine sponges: A new model for understanding silicon isotopic variations in sponges, Earth Planet. Sc. Lett., 292, 281-289, https://doi.org/10.1016/j.epsl.2010.01.036, 2010. 